\title{
Intercontinental transport of pollution and dust aerosols: implications for regional air quality
}

\author{
Mian Chin ${ }^{1}$, T. Diehl ${ }^{2}$, P. Ginoux ${ }^{3}$, and W. Malm ${ }^{4}$ \\ ${ }^{1}$ NASA Goddard Space Flight Center, Greenbelt, MD, USA \\ ${ }^{2}$ University of Maryland Baltimore County, Baltimore, MD, USA \\ ${ }^{3}$ NOAA Geophysical Fluid Dynamics Laboratory, Princeton, NJ, USA \\ ${ }^{4}$ National Park Service, CIRA, Colorado State University, Fort Collins, CO, USA
}

Received: 8 June 2007 - Published in Atmos. Chem. Phys. Discuss.: 26 June 2007

Revised: 4 October 2007 - Accepted: 8 October 2007 - Published: 1 November 2007

\begin{abstract}
We use the global model GOCART to examine the impact of pollution and dust aerosols emitted from their major sources on surface fine particulate matter concentrations at regional and hemispheric scales. Focusing on the North America region in 2001, we use measurements from the IMPROVE network in the United States to evaluate the modelsimulated surface concentrations of the "reconstructed fine mass" (RCFM) and its components of ammonium sulfate, black carbon (BC), organic matter (OM), and fine mode dust. We then quantify the RCFM budget in terms of the RCFM chemical composition, source type, and region of origin to find that in the eastern U.S., ammonium sulfate is the dominant RCFM component ( $\sim 60 \%)$ whereas in the western U.S., dust and OM are just as important as sulfate but have considerable seasonal variations, especially in the NW. On an annual average, pollution aerosol (defined as aerosols from fuel combustion for industrial and transportation uses) from North America accounts for $65-70 \%$ of the surface RCFM in the eastern U.S. and for a lower proportion of $30-40 \%$ in the western U.S.; by contrast, pollution from outside of North America contributes to just $2-6 \%\left(\sim 0.2 \mu \mathrm{g} \mathrm{m}^{-3}\right)$ of the total RCFM over the U.S. In comparison, long-range transport of dust brings 3 to 4 times more fine particles than the transport of pollution to the U.S. $\left(0.5-0.8 \mu \mathrm{g} \mathrm{m}^{-3}\right.$ on an annual average) with a maximum influence in spring and over the NW. Of the major pollution regions, Europe has the largest potential to affect the surface aerosol concentrations in other continents due to its shorter distance from receptor continents and its larger fraction of sulfate-producing precursor gas in the outflow. With the IPCC emission scenario for the year 2000, we find that European emissions increase levels of ammonium sulfate by $1-5 \mu \mathrm{g} \mathrm{m}^{-3}$ over the surface of northern Africa and western Asia, and its contribution to eastern Asia

Correspondence to: Mian Chin

(mian.chin@nasa.gov)
\end{abstract}

$\left(\geq 0.2 \mu \mathrm{g} \mathrm{m}^{-3}\right.$ ) is twice as much as the Asian contribution to North America. Asia and North America pollution emissions exert strong impacts on their neighboring oceans, but their influences over other continents are relatively small $(\leq 10 \%)$ due to long traveling distances across the oceans and efficient removal during transport. Among the major dust source regions, Asia displays a significant influence over large areas in the northern hemisphere except over the North Atlantic and the tropics, where African dust dominates. We also notice that the African dust and European pollution can travel eastward through a pathway spanning across Asia and North Pacific to western North America; such a pathway is difficult to detect because these aerosols usually merge and travel together with Asian dust and pollution labeled as "Asian outflow".

\section{Introduction}

Aerosol, also known as particulate matter (PM), is one of the major air pollutants determining ambient air quality. Airborne particle sizes vary widely from a few $\mathrm{nm}\left(10^{-9} \mathrm{~m}\right)$ to a few hundred $\mu \mathrm{m}$ in diameter; those with diameters smaller than $10 \mu \mathrm{m}\left(\mathrm{PM}_{10}\right)$ are of health concern because they can penetrate into the lungs, and those smaller than $2.5 \mu \mathrm{m}\left(\mathrm{PM}_{2.5}\right)$ pose the most serious risks to human health, being linked to respiratory or cardiovascular diseases and even deaths (Ostro et al., 1999, 2000; World Health Organization, 2002; Pope, 2002). Aerosol is also known to cause regional haze, which leads to discoloration, loss of texture, and deterioration of visual range in national parks and wilderness areas (Malm et al., 2000). Sources of PM include both direct emissions and chemical transformations of precursor gases emitted from power plants, automobiles, wood

Published by Copernicus Publications on behalf of the European Geosciences Union. 

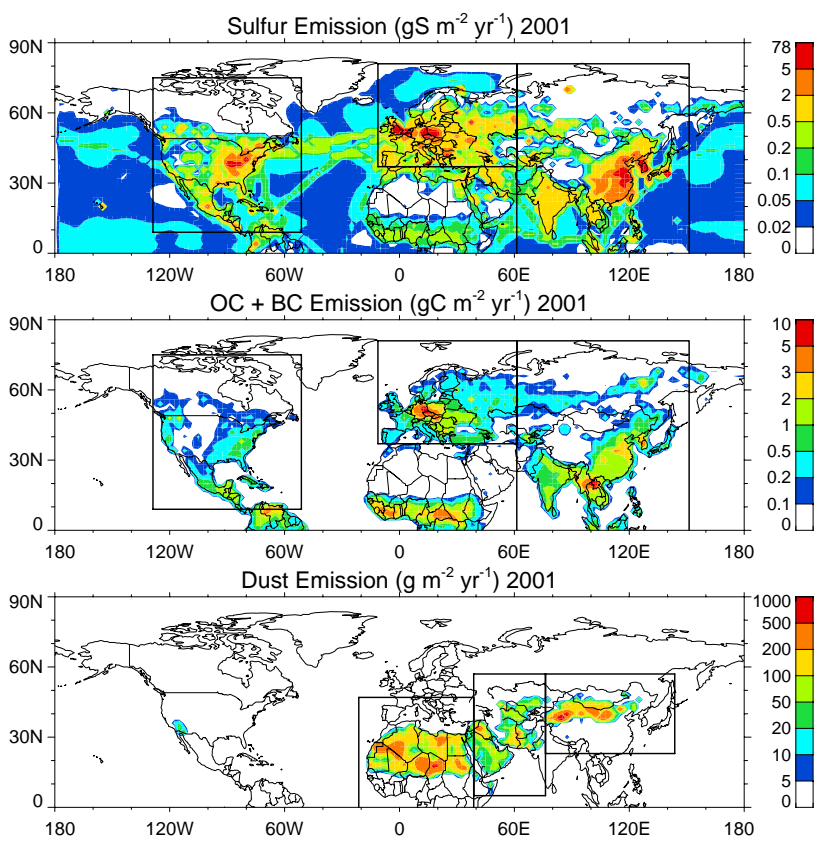

Fig. 1. Annual average emissions of sulfur $\left(\mathrm{SO}_{2}\right.$, sulfate, and DMS), carbonaceous (BC and OC), and dust in 2001 used in the GOCART model. Domains of three major industrial pollution regions of Asia, Europe, and North America are shown in the 1st and 2nd panels and three major dust regions of Asia, Middle East/Central Asia, and northern Africa are shown in the 3rd panel.

burning, forest and agriculture fires, and natural sources (e.g., dust, volcanoes, vegetation).

Airborne PM concentration has been regulated in the United States by the Clean Air Act since 1970. Currently, the indices of "good" air quality for $\mathrm{PM}_{10}$ and $\mathrm{PM}_{2.5}$ in the U.S. are $50 \mu \mathrm{g} \mathrm{m}^{-3}$ and $15 \mu \mathrm{g} \mathrm{m}^{-3}$ on an annual average, respectively, as set by the U.S. Environmental Protection Agency. Recognizing the importance of visual air quality, the U.S. Congress included legislation in the 1977 Clean Air Act to remedy existing and prevent future visibility impairment in national parks and wilderness areas. Although pollutant emissions in the U.S. are projected to decrease in the next 100 years (IPCC, 2001), the long-range transport of aerosols from other regions in the world could increase the surface PM level and may reduce the benefits generated from local emission controls. Recently, much attention has been focused on assessing the long-range transport of aerosols from Asia to North America. Situated upwind of North America across the Pacific Ocean, Asia is the fastest economically developing region and has large active deserts, from which the trans-Pacific transport can bring an increasingly significant amount of pollution and dust to North America. For example, episodes of elevated sulfate concentrations that were observed in the northwestern U.S. in springtime were attributed to Asian emissions (Jaffe et al., 2003; Bertschi et al., 2004), and satellite images have clearly revealed the trans-Pacific transport of Asian dust during dust storm events, which bring large amounts of dust to western North America and strongly affect the radiation budget and air quality (Husar et al., 2001). Previous global modeling studies have estimated that trans-Pacific Asian pollution could account for $30 \%$ of "background" surface sulfate concentrations over the U.S. (i.e., concentration without U.S. anthropogenic emission) (Park et al., 2004). Such transport usually peaks in the spring season and can add $0.16 \mu \mathrm{g} \mathrm{m}^{-3}$ sulfate to the northwestern U.S. (Heald et al., 2006). It is estimated that the Southeast Asia is the largest contributor of the black carbon (BC) over the Arctic and is also partially responsible for the "Arctic haze" (Koch and Hansen, 2005; Koch et al., 2007) - the phenomenon of a visible reddishbrown haze in the atmosphere at high latitudes in the Arctic due to air pollution (e.g. Shaw, 1995). A recent modeling study has estimated that the trans-Pacific transport of BC from Asia into North America could amount to $>70 \%$ of the BC emitted in North America, although the effects are evident mostly at altitudes above the North American boundary layer (Hadley et al., 2007).

In the meantime, major economically developed regions such as the U.S. and Europe remain important pollution sources. The impact of the North American export of ozone and its precursors on the surface ozone over Europe has been extensively studied, showing a maximum impact during the summer time (Stohl and Trickl, 1999; Wild et al., 2001; Li et al., 2002, 2005; Guerova et al., 2006). Similarly, European pollution increases the surface ozone concentrations over northern Africa, the Mediterranean, and the Near East to a level that exceeds the European Council's human health standards (Stohl et al., 2002; Duncan and Bey, 2004). The transport of sulfate aerosol from Europe and North America to the Arctic has been identified as a major cause of the "Arctic haze". So far, however, most of those studies on hemispheric transport have primarily dealt with ozone and individual aerosol species (e.g., sulfate or carbonaceous) or column aerosol quantities, leaving large gaps in a comprehensive assessment of the surface PM levels that are determined from regional emissions and long-range transport.

To fill such gaps, we present here an assessment of intercontinental transport of aerosols and its implication for regional air quality with the Goddard Chemistry Aerosol Radiation and Transport (GOCART) model. Focusing on the surface aerosol mass concentrations, we try to (1) quantify the surface fine aerosol mass concentrations over the U.S. that come from regional pollutant emission, natural sources, and intercontinental transport, and then (2) examine the source-receptor relationships between the major pollution and dust source regions and downwind areas in the northern hemisphere. We choose the year 2001 in this study, which has been used in our previous analysis of satellite and ground-based sunphotometer measurements of aerosol optical thickness (AOT) and aircraft data from the ACEAsia field experiments (Chin et al., 2003, 2004). We will 


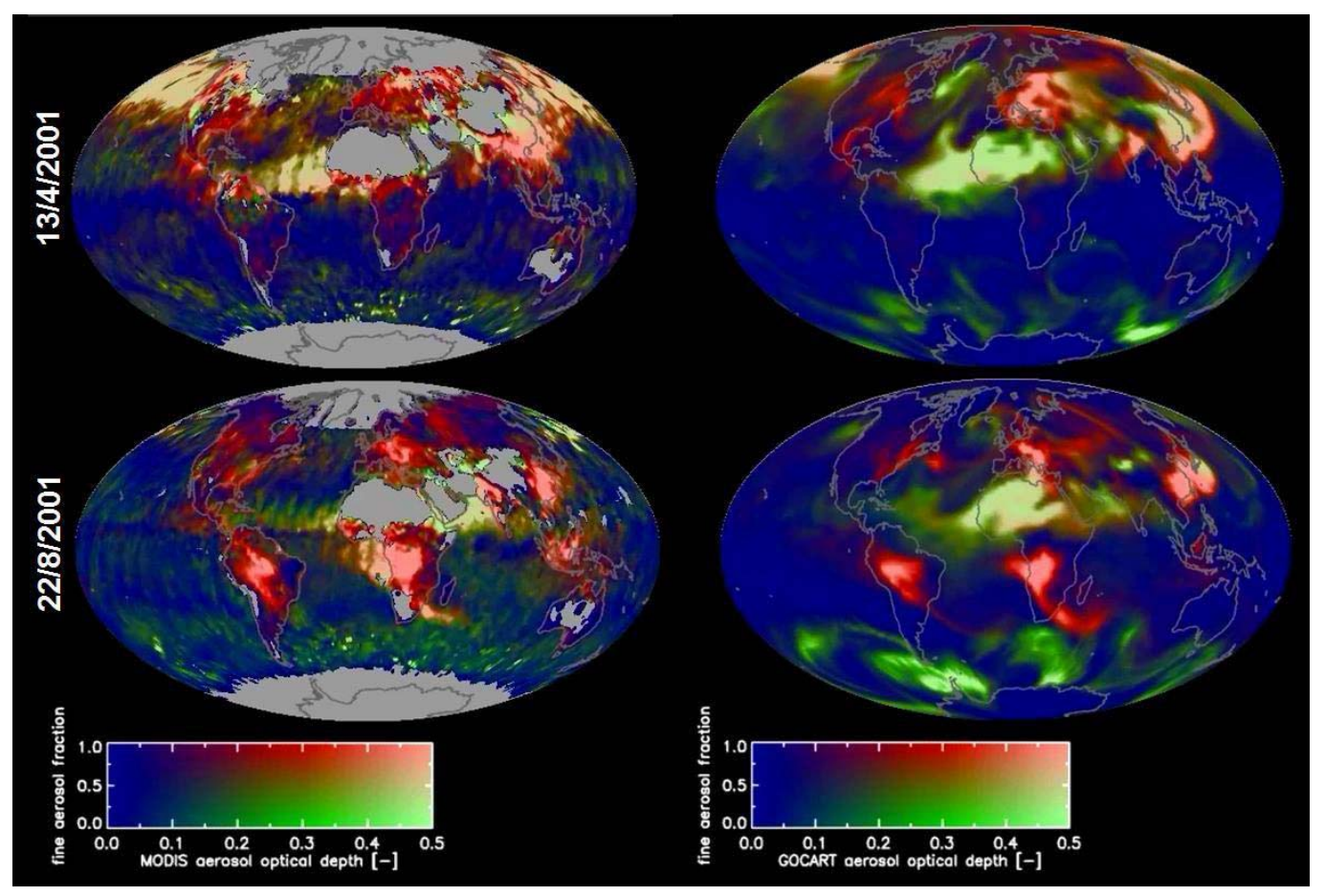

Fig. 2. Aerosol optical depth observed by the MODIS instrument on EOS-Terra (left column) and simulated by the global model GOCART (right column) for 13 April (top row) and 22 August (bottom row), 2001. Red color indicates fine mode aerosols (e.g., pollution and smoke) and green color coarse mode aerosols (e.g., dust and sea-salt). Brightness of the color is proportional to the aerosol optical depth. On 13 April 2001, there are heavy dust and pollutions transported from Asia to the Pacific and dust transported from Africa to Atlantic; while on 22 August large smoke plumes from South America and Southern Africa are evident. Figure credit: Yoram Kaufman and Reto Stöckli.

briefly describe the model (Sect. 2), compare the model simulated surface aerosol concentrations with measurements in the U.S. (Sect. 3), provide assessments of the impact of emissions and long-range transport on the U.S. surface air quality (Sect. 4), and examine the hemispheric influence of the intercontinental transport (Sect. 5), followed by conclusions (Sect. 6).

\section{GOCART model simulation of global aerosol distri- butions}

The GOCART model is used to simulate major tropospheric aerosols including sulfate, dust, black carbon (BC), organic carbon (OC), and sea-salt. Detailed descriptions of the model have been presented in our previous publications (Chin et al., 2000a, b, 2002, 2004; Ginoux et al., 2001, 2004) with a few modifications applied to this work. We use assimilated meteorological fields from the NASA Goddard Earth Observing System version 3 Data Assimilation System (GEOS-3 DAS) for 2001 with a spatial resolution of $2^{\circ}$ latitude by $2.5^{\circ}$ longitude and 30 vertical layers. Processes in the model include emission, chemistry, convection, advection, boundary layer mixing, dry and wet deposition, and gravitational settling. AOT is calculated from dry mass concentrations and mass extinction coefficients which are determined from the size distributions, refractive indices, and hygroscopic properties of the individual aerosol types as a function of ambient relative humidity (Chin et al., 2002).

Emissions in the model include fossil fuel and biofuel combustion, biomass burning, biogenic and volcanic sources, desert dust, and sea-salt. Those aerosols that originate from fuel combustion are referred to in this study as "pollution" aerosols. Fuel combustion sources are taken from the IPCC Special Report of Emission Scenarios (SRES) for the year 2000 (Nakienovi et al., 2000) for $\mathrm{SO}_{2}$ and from Cooke et al. (1999) for BC and OC. Biofuel emissions of BC and OC are based on a recent assessment of biofuel use (Yevich and Logan, 2003) with emission factors of $0.6 \mathrm{~g} \mathrm{BC}$ and $4.0 \mathrm{~g} \mathrm{OC}$ per $\mathrm{kg}$ dry mass consumed. Biomass burning emissions in 2001 are based on the monthly dry mass burned data from the Global Fire Emission Dataset (van der Werf et al., 2003), using emission factors of 8,1 , and $1.1 \mathrm{~g} \mathrm{~kg}^{-1}$ for $\mathrm{OC}, \mathrm{BC}$, and $\mathrm{SO}_{2}$, respectively. These emission factors have been somewhat modified from our previous work but remain within the range of the values reported in the literature (see Chin et al., 2002). Dust and sea-salt emissions for particle size from 0.1 to $10 \mu \mathrm{m}$ (dry radius) are calculated as a function of surface properties and wind speed (Ginoux et al., 2001; 
Table 1. Global total emissions of aerosols and precursors in 2001 used in this study.

\begin{tabular}{|c|c|}
\hline Sulfur $\left(\operatorname{TgS~yr}^{-1}\right)^{\mathrm{a}}$ Total & 90.7 \\
\hline Pollution & 64.9 \\
\hline Asia & 26.3 \\
\hline Europe & 17.3 \\
\hline North America & 12.3 \\
\hline Other & 9.0 \\
\hline Biomass burning & 3.5 \\
\hline Natural & 22.3 \\
\hline Ocean & 13.6 \\
\hline Volcano & 8.7 \\
\hline $\mathrm{OC}\left(\mathrm{TgC} \mathrm{yr}^{-1}\right)$ Total & 82.3 \\
\hline Pollution & 19.6 \\
\hline Asia & 9.4 \\
\hline Europe & 6.1 \\
\hline North America & 1.0 \\
\hline Other & 3.1 \\
\hline Biomass burning & 50.0 \\
\hline Natural $^{\mathrm{b}}$ & 12.7 \\
\hline $\mathrm{BC}\left(\mathrm{TgC} \mathrm{yr}^{-1}\right)$ Total & 14.1 \\
\hline Pollution & 7.8 \\
\hline Asia & 3.6 \\
\hline Europe & 2.5 \\
\hline North America & 0.7 \\
\hline Other & 1.0 \\
\hline Biomass burning & 6.3 \\
\hline Dust $\left(\mathrm{Tg} \mathrm{yr}^{-1}\right)^{\mathrm{c}}$ Total & 2773 \\
\hline Asia & 566 \\
\hline Middle East & 443 \\
\hline Northern Africa & 1609 \\
\hline Other & 155 \\
\hline Sea-salt $\left(\mathrm{Tg} \mathrm{yr}^{-1}\right)^{\mathrm{c}}$ Total & 9838 \\
\hline
\end{tabular}

a Sulfur source includes $\mathrm{SO}_{2}(\sim 97 \%)$ and sulfate $(\sim 3 \%)$ from industrial and transportation emissions (referred as "pollution"), dimethyl sulfide (DMS) from ocean, $\mathrm{SO}_{2}$ from biomass burning and volcanoes.

b Natural OC is from terpene oxidation.

${ }^{\mathrm{c}}$ Dust and sea-salt emissions include the size range up to $10 \mu \mathrm{m}$ in radius.

Chin et al., 2002, 2004). In addition, biogenic and volcanic emissions are also included in the model. The global annual emissions of total sulfur (mostly in the form of $\mathrm{SO}_{2}$ over land and dimethylsulfide, or DMS, over ocean), carbonaceous species (OC and BC), and dust for year 2001 are listed in Table 1, with the northern hemispheric emission pattern shown in Fig. 1. Major industrial pollution regions in the northern hemisphere, identified as North America, Europe, and Asia, account for about $85 \%$ of global pollution sources of $\mathrm{SO}_{2}, \mathrm{BC}$, and OC. As for dust, more than $90 \%$ is emitted from desert regions of northern Africa, Middle East (including Central Asia), and Asia (including China and Mongolia), with almost $60 \%$ from northern Africa (Table 1). The domains of three major anthropogenic source regions are outlined in Fig. 1a and $1 \mathrm{~b}$ and three major dust regions in Fig. 1c. The impact of these regional emissions will be analyzed in Sects. 3 and 4.

Our previous analyses of the satellite and ACE-Asia field experiment data for spring 2001 have shown that the observed aerosol distributions and long-range transport were adequately captured by the model (Chin et al., 2003, 2004). Figure 2 illustrates the global fields of AOT, separated by fine mode (red) and coarse mode (green) components, on 13 April and 22 August 2001 observed by the Moderate Resolution Imaging Spectroradiometer (MODIS) instrument on the EOS-Terra satellite and simulated by the GOCART model. The fine mode AOT consists mainly of pollution and biomass burning aerosols while the coarse mode consists mainly of dust and sea-salt aerosols. On 13 April 2001, the crossPacific transport of dust and pollution from Asia to North America and the cross-Atlantic transport of dust from Africa to Central America are clearly revealed, while on 22 August large smoke plumes from South America to the southern Atlantic and from southern Africa to the Indian Ocean are evident from both MODIS and the model. The impact of such large-scale transport on the receptor region's air quality depends on the perturbation of the surface aerosol concentrations, which we will discuss in the following sections.

\section{Surface aerosol concentrations over the U.S. from IM- PROVE and model}

\subsection{IMPROVE data}

Our model results for surface aerosol concentrations are evaluated here with observations over the U.S. from the Interagency Monitoring for Protected Visual Environments (IMPROVE) network. The IMPROVE program was initiated in 1985 by the U.S. federal agencies EPA, National Park Services, Department of Agriculture-Forest Service, and other land management agencies as a part of the EPA Regional Haze program (Malm et al., 1994). IMPROVE has implemented an extensive, long-term monitoring program in order to establish current visibility conditions and track visibility changes in national parks and wilderness areas. There are more than 100 IMPROVE sites in the U.S. routinely measuring aerosol chemical compositions as well as fine and coarse mode aerosol mass concentrations (http://vista.cira.colostate. edu/IMPROVE). The locations of the IMPROVE sites that provided data in 2001 are shown in Fig. 3. We divide the U.S. into four quadrants, NW, SW, NE, and SE with dividing lines along $40^{\circ} \mathrm{N}$ and $100^{\circ} \mathrm{W}$, to differentiate regional features. 
The fine mode aerosol species of sulfate, OC, BC, and dust from IMPROVE are used in this study. While sulfate particles are collected on a nylon filter and analyzed by ion chromatography, OC and BC (aka elemental carbon or EC) are derived based on thermal optical reflectance combustion, a process that involves multiple steps including heating the sample and oxidizing/reducing the carbon to different chemical compounds (e.g. $\mathrm{CO}_{2}, \mathrm{CH}_{4}$ ) (see Malm et al., 1994 for details). As such, the reported $\mathrm{OC}$ and $\mathrm{BC}$ data from the IMPROVE sites have relatively larger uncertainties than sulfate. The mass of soil dust is calculated from a linear combination of the measured elements associated predominantly with soil, including Al, $\mathrm{Si}, \mathrm{Ca}, \mathrm{Fe}$, and Ti (Malm et al., 1994); uncertainties associated with the reported dust values reflect the range and variation of mineral composition from a variety of soil types. Finally, in addition to $\mathrm{PM}_{2.5}$ and $\mathrm{PM}_{10}$, IMPROVE also reports the quantity of "reconstructed fine mass" (RCFM), which is the sum of mass concentrations of ammonium sulfate, organic matter (OM), BC, and fine dust particles (diameter less than $2.5 \mu \mathrm{m}$ ). Nitrate and sea-salt are excluded from the RCFM because of the significant loss of nitrate particles during sampling and the negligible amount of sea-salt at most of the sites (Malm et al., 1994). We will therefore use the quantity of RCFM in this study, which is particularly appropriate because the GOCART model does not include nitrate. The IMPROVE measurements showed that concentrations of RCFM are very close to that of $\mathrm{PM}_{2.5}$ in most places over the U.S., except in California where nitrate can make up a significant fraction of $\mathrm{PM}_{2.5}$ (Malm et al., 1994, 2003). In the reported RCFM, ammonium sulfate mass is converted from the measured sulfate ion by multiplying a factor of 1.375 , assuming that sulfate exists mainly in the form of ammonium sulfate (although a small fraction of sulfate can exist as ammonium bisulfate or sulfuric acid), and the $\mathrm{OM}$ is estimated by applying a correction factor of 1.4 to the OC mass concentrations to account for non-carbon mass contained in the organic carbon aerosol (Malm et al., 1994, 2003). The same conversion factors are applied to the modelcalculated sulfate and OC to construct the modeled value of RCFM.

\subsection{Composition of surface fine aerosol mass over the U.S.}

Daily variations in surface aerosol species and RCFM concentrations are illustrated in Fig. 4 at four IMPROVE sites, each located in the NW, SW (in Fig. 4a), NE, and SE (in Fig. 4b) quadrants. At the NW site of Sula, Montana (SULA1), the seasonal variation of RCFM exhibits two maxima, one in the spring (April-May) controlled mainly by dust from long-range transport, and the other in the summer (July-August) caused by carbonaceous (OC and BC) from biomass burning. At the SW site of Bandelier National Monument, New Mexico (BAND1), dust is the major aerosol component; most of which is from the nearby Sonora Desert (located at southwestern Arizona and southeastern Califor-

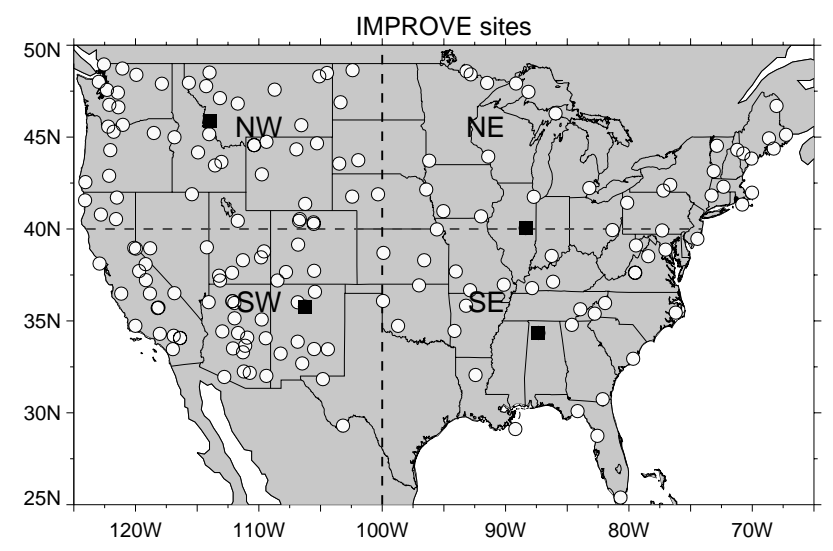

Fig. 3. Location of IMPROVE sites in 2001 and dividing lines of the NW, SW, NE, SE quadrants. Data from the four sites highlighted in solid squares are compared with model in detail in Fig. 4.

nia) but the spring peak is caused by the trans-Pacific transport from Asia (see Fig. 2 and Sect. 4). The model successfully captures the seasonal variations of dust and biomass burning aerosols and reproduces the sulfate levels at these sites. However, its $\mathrm{BC}$ and $\mathrm{OC}$ concentrations in the first and last quarter of the year are much lower than the measurements (average $80 \%$ lower). This may be explained in part by the fact that we did not consider the seasonal variation of anthropogenic $\mathrm{BC}$ and $\mathrm{OC}$ emissions which are suggested to be 15 to $50 \%$ higher in the winter than in the summer (Park et al., 2003).

The two eastern sites (Fig. 4b), Bondville, Illinois (BOND1) in NE and Sipsy, Alabama (SIPS1) in SE show much higher RCFM concentrations than the two western sites in the U.S. (Fig. 4a) mainly because of much stronger industrial pollution emissions in the eastern U.S. (Fig. 1). The model attributes the increase of $\mathrm{BC}$ and $\mathrm{OC}$ in November to biomass burning, but it misses the high episode in March that is likely also from biomass burning. However, these episodic events cannot be resolved by the monthly averaged fire emission data we used in the model. Fine dust at the two eastern sites shows a spring maximum which is connected with long-range transport, a feature rather similar to that displayed in Fig. 4a for the western sites.

Comparisons of monthly averaged concentrations of RCFM between the measurements and the model at 135 IMPROVE sites for 2001 are plotted in Fig. 5. The majority of these values agree to within a factor of 2 ; the points where the model is more than 2 times higher or lower than the data are mostly from the disagreement in fine dust (higher in the model) and carbonaceous (lower in the model) concentrations. Overall, the model captures the IMPROVE reported RCFM levels and seasonal variations with small bias as indicated by the relatively high correlation coefficient $(R)$, low bias $(B)$, and high skill score $(S)$, but the statistics are different for each RCFM component, as listed in Table 2. The 



Fig. 4a. Daily concentrations of sulfate, BC, OC, fine-mode dust, and reconstructed fine mass (RCFM) at IMRPOVE sites of Sula, Montana (SULA1) in the NW sector (see Fig. 3) and Bandelier National Monument, New Mexico (BAND1) in the SW sector in 2001. Vertical grey line: IMPROVE data; black dots: GOCART model simulations. Showing on each panel: $R=$ correlation coeficient, $E=$ standard error, $B=$ relative bias, and $S=$ skill score which is computed from standard deviations and correlation coefficient (Taylor, 2001; also see Chin et al., 2003, 2004).

model shows the best skill in simulating sulfate $(R=0.82$, $B=1.15, S=0.88$ ), but its simulated carbonaceous aerosol concentrations (especially OC) are lower and fine dust concentrations are higher than the IMPROVE reported values and with lower correlation coefficients $(R=0.5-0.6)$. This discrepancy reflects partly the deficiencies in the model, such as a lack of seasonal variation of $\mathrm{BC}$ and $\mathrm{OC}$ emissions from fossil fuel and biofuel combustion, as discussed earlier, or insufficient removal of dust during transport. On the other hand, uncertainties in the IMPROVE carbonaceous and dust aerosol data are also relatively high because they are either inferred from optical/thermal measurements (for BC and $\mathrm{OC}$ ) or derived from a combination of multiple mineral elements (for dust) as described in Sect. 3.1. Another contributing factor for the discrepancy between the model and
IMPROVE data is the spatial difference: the point measurements from individual IMPROVE sites may not be representative of the model output for the grid cell area of $2^{\circ}$ latitude $\times 2.5^{\circ}$ longitude. Averaging the data from a group of sites located in the same model grid cell would be a fairer approach to evaluating the model, but there are only a handful of cases where one model grid cell contains 3 or more sites (the 135 sites spread in 92 grid cells) to achieve better statistics (the grid cell-averaged comparisons are also listed in Table 2).

The observed and modeled seasonal cycles of RCFM and its composition averaged over all the IMPROVE sites located in each domain of NW, SW, NE, and SE are shown in Fig. 6. The model and IMPROVE data show many similar features in the seasonal variation and RCFM composition; for example, the distinct two RCFM peaks in the NW 

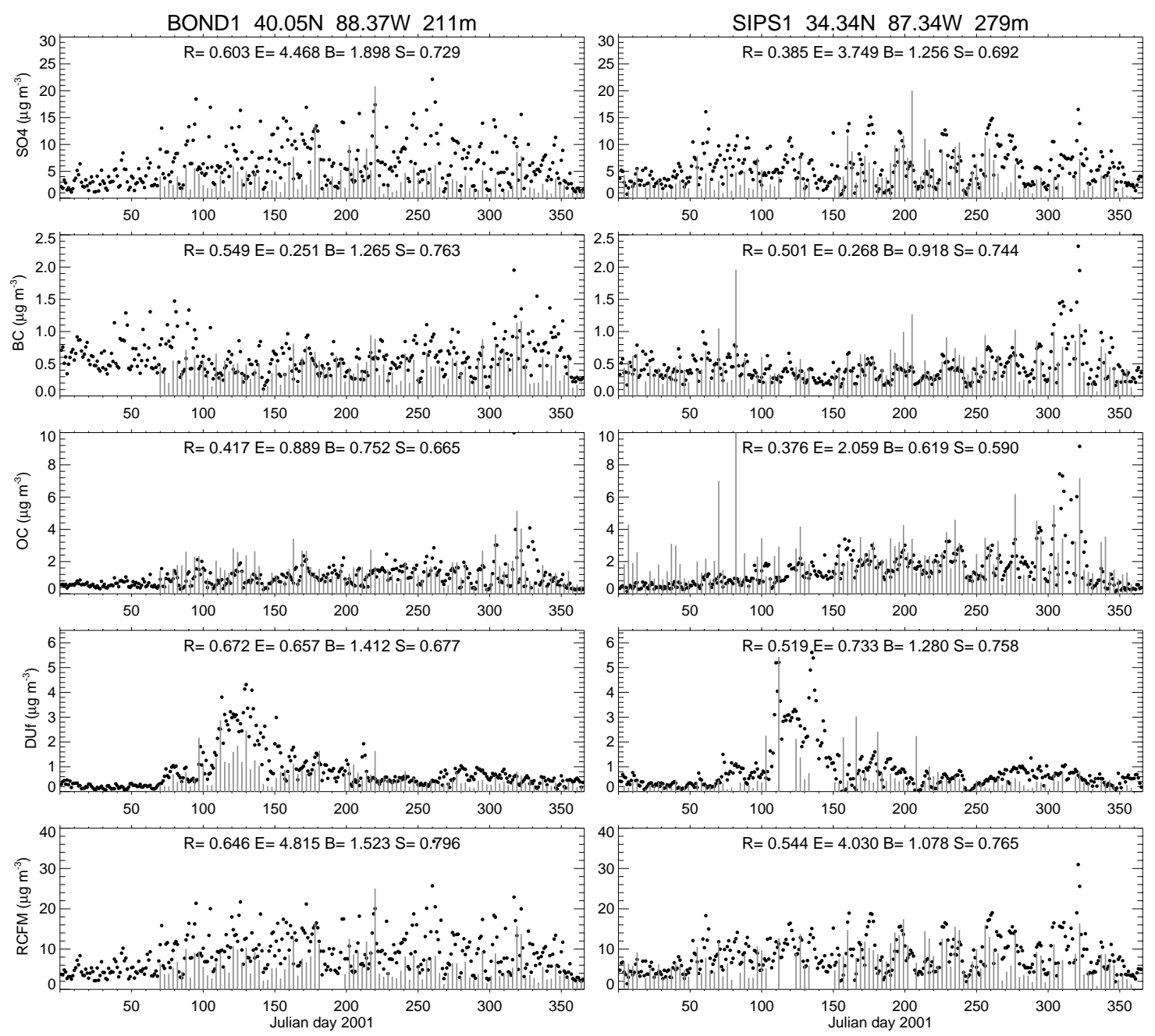

Fig. 4b. Same as in Fig. 4a but at Bondville, Illinois (BOND1) in the NE sector and Sipsy Wilderness, Alabama (SIPS1) in the SE sector.

(one in April-May mainly from the long-range transport of dust and one in August dominated by the OM from biomass burning) and the clear dominance of sulfate in the eastern U.S. (more than 60\%). The annual averaged RCFM concentrations are highest in the SE $\left(>8 \mu \mathrm{g} \mathrm{m}^{-3}\right)$ and lowest in the NW $\left(\sim 3 \mu \mathrm{g} \mathrm{m}^{-3}\right)$, with NE $\left(5-6 \mu \mathrm{g} \mathrm{m}^{-3}\right)$ and SW $\left(\sim 3.5 \mu \mathrm{g} \mathrm{m}^{-3}\right)$ in between. Both observation and the model indicate that BC makes up just $4-6 \%$ of RCFM across the U.S., although it is the most important species for light absorption and aerosol atmospheric heating. One noticeably large difference between the model and IMPROVE data is the ammonium sulfate in the SE: the model estimates a summer valley while IMPROVE shows a summer peak. The strong convective scavenging in the SW region from the model seems to be responsible for the summer minimum, which efficiently removes not only sulfate but also its precursor $\mathrm{SO}_{2}$ to reduce the sulfate production (Chin et al., 2000b). Similar to what was seen in Fig. 4 and Table 2, Fig. 6 again reveals
Table 2. Statistics between the model-calculated and IMPROVE measured monthly mean concentrations of aerosol species at 135 IMPROVE sites (or in 92 model grid cells) over the U.S.

\begin{tabular}{lccc}
\hline & $R$ & $B$ & $S$ \\
\hline Sulfate & $0.815(0.815)$ & $1.154(1.148)$ & $0.879(0.884)$ \\
BC & $0.519(0.558)$ & $0.884(0.928)$ & $0.680(0.648)$ \\
OC & $0.454(0.517)$ & $0.568(0.582)$ & $0.721(0.748)$ \\
Fine dust & $0.577(0.607)$ & $1.747(1.711)$ & $0.687(0.652)$ \\
RCFM & $0.756(0.775)$ & $1.052(1.051)$ & $0.873(0.882)$ \\
\hline
\end{tabular}

$R=$ correlation coefficient $B=$ relative bias; $S=$ skill score computed from standard deviations and correlation coefficient (Taylor, 2001; also see Chin et al., 2003, 2004). Values in parenthesis are corresponding quantities when the data from a group of sites located in the same model grid cell are averaged. 


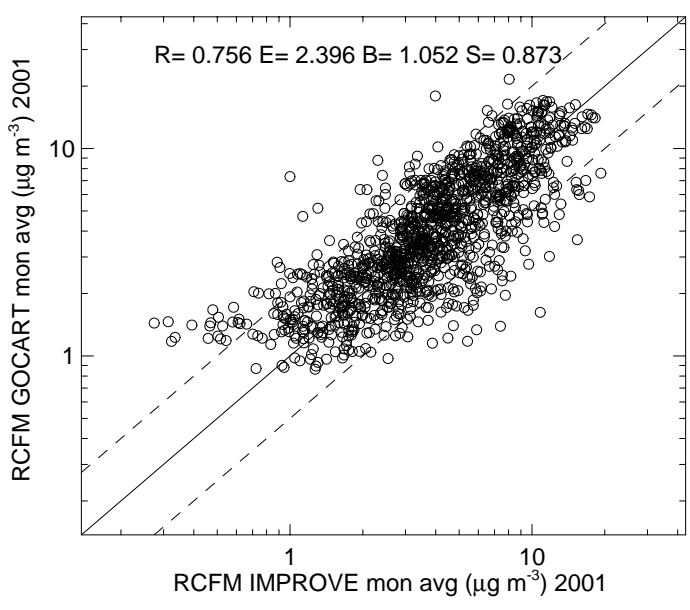

Fig. 5. Scatter plot of monthly averaged surface RCFM concentrations over the IMPROVE sites (location in Fig. 3).

the difference of fine dust and OM between the data and the model: the transported dust (in spring) is higher and the nonbiomass burning $\mathrm{OM}$ is lower in the model. In any case, this discrepancy suggest that the model may underestimate the influence of North American regional sources but overestimate that of long-range transport on the surface RFCM over the U.S., since most OM aerosols are generated by the North American sources while most dust is transported into the U.S. (see Sect. 4).

\section{Origins of surface aerosols over the U.S.: regional sources vs. intercontinental transport}

Having analyzed the spatial and temporal variations of the surface RCFM over the U.S., we now try to quantify the amount of RCFM from regional pollution sources that may be regulated by air quality management as opposed to the amount from natural sources or from long-range transport that are difficult to control. We have conducted a series of model experiments to estimate the RCFM from North American pollution sources vs. "background" (i.e. from natural and long-range transport), and from total regional sources (pollution, natural, and biomass burning) vs. intercontinental transport. The model experiments are designed in such a way that emissions from a selected source type (e.g., fossil fuel, biomass burning, dust) or source region (e.g., Asia, Europe, Africa) are excluded in each model run, and the difference between the "standard" run with all emissions included and the runs with a particular source type or region excluded is considered as the contribution from that source type or region. We categorize the source types as those tabulated in Table 1: "pollution", which includes emissions from fossil fuel and biofuel consumptions, "biomass burning", which includes both natural wild fires and burning from agriculture waste or land management practice, and "natural", which in- cludes emissions from ocean, vegetation, deserts, and volcanoes.

The seasonal cycles of model-calculated RCFM from different source categories are shown in Fig. 7 for the four quadrants in the U.S. with annual averaged values (composition and origin) tabulated in Table 3. The domain averaged surface RCFM from the model are 3.43, 4.91, 5.36, $8.32 \mu \mathrm{g} \mathrm{m}^{-3}$ for NW, SW, NE, and SE, respectively. Note these values are somewhat different from the ones listed in Fig. 6 that were averaged over the IMPROVE site locations rather than over the complete quadrant domains shown here.

The North American regional pollution (NAM, red shade in Fig. 7) dominates the total surface RCFM in the eastern half of the U.S., accounting for $71 \%$ and $65 \%$ of the budget in the NE and SE, respectively, whereas its contributions are considerably smaller in the western half of the U.S., with $28 \%$ in the NW and 38\% in the SW. While North American pollution aerosols have relatively small seasonal variations,

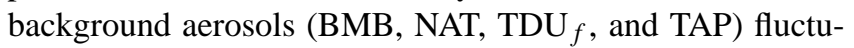
ate considerably by season and region. For example, biomass burning aerosol contribution can change from zero during non-burning seasons to dominant in the peak burning season; likewise, fine dust concentrations during the peak transport season can be hundreds of times higher than those in the "quiet" seasons. Thus, the significance of the background aerosol hinges with location and time, with the largest variation in the NW.

The total amount of RCFM from the intercontinental transport is the sum of pollution and fine dust originating in regions other than North America (TAP+TDU $f$ in Fig. 7 and Table 3) with a majority being dust (70-80\%). Although other natural aerosols, i.e. volcanic or biogenic aerosols, can also undergo long-range transport, their influence on the surface of receptor regions is expected to be much smaller than that of pollution and dust aerosols, unless major volcanic eruptions occur. On an annual and area average basis, the intercontinental transport raises RCFM levels in the NW, SW, $\mathrm{NE}$, and SE regions by $1.0,0.91,0.72$, and $0.75 \mu \mathrm{g} \mathrm{m}^{-3}$, respectively, corresponding to $30 \%, 19 \%, 14 \%$, and $9 \%$ of the total RCFM in those regions. These values could even be too high considering that the model estimated fine dust, most of which comes from outside of North America, is over 70\% higher than the IMPROVE data. Therefore, our model results suggest that on an annual basis, the majority of the surface fine mass over the U.S. is from North American regional sources, including pollution, biomass burning, and natural sources.

The pollution originating from other continents that is transported into the U.S. (TAP, dark purple in Fig. 7) provides about $0.2 \mu \mathrm{g} \mathrm{m}^{-3}$ RCFM to the U.S. on an annual average, which is only $2-6 \%$ of the total surface RCFM across the U.S. Even during the most active intercontinental transport seasons (spring) over the surface of the most vulnerable region (NW), the transported pollution RCFM is still only about $0.5 \mu \mathrm{g} \mathrm{m}^{-3}$. This implies that the pollutant emissions 

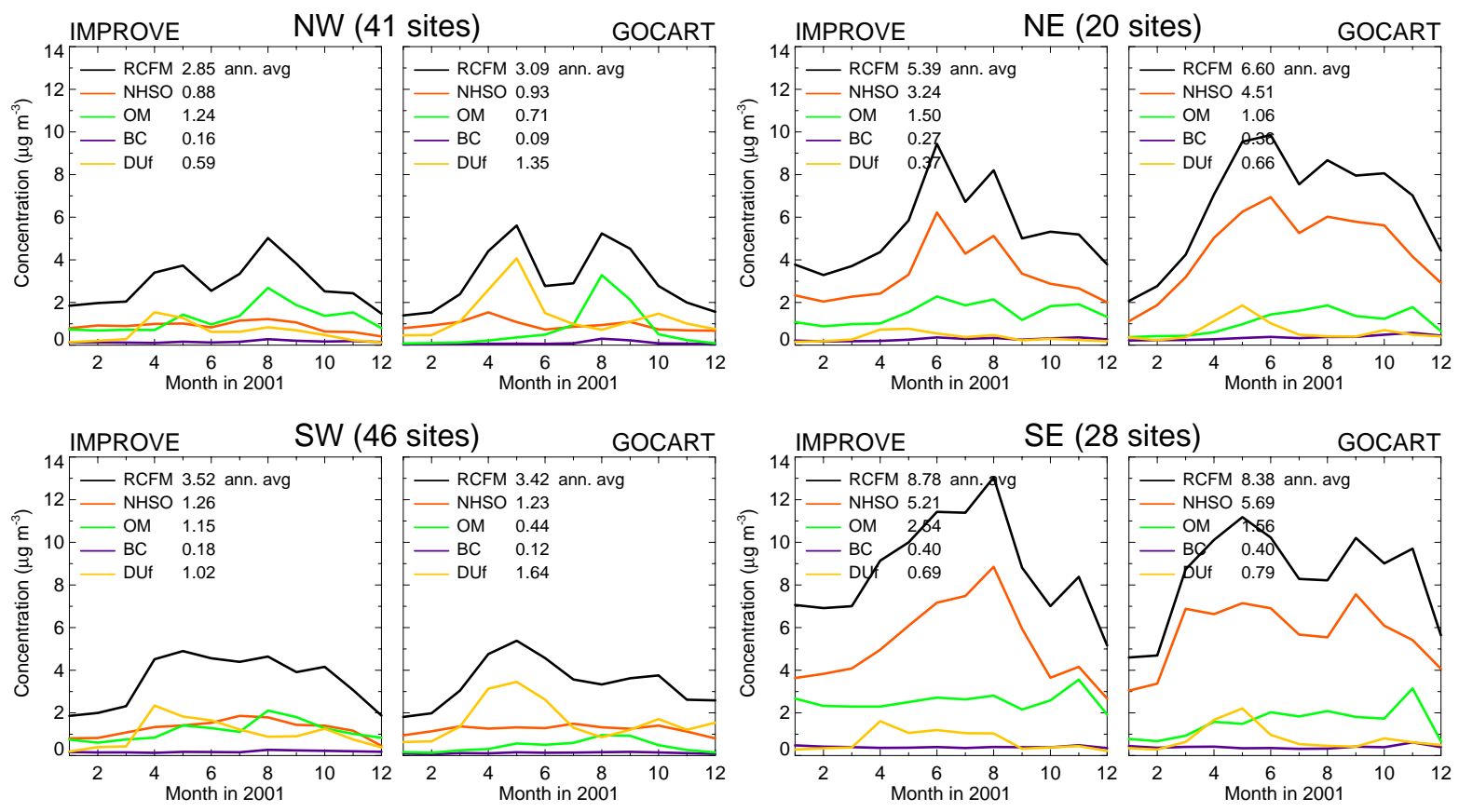

Fig. 6. Seasonal cycles of surface RCFM $\left(\mu \mathrm{g} \mathrm{m}^{-3}\right)$ and its composition in 2001 from both IMPROVE data and GOCART model, averaged over the IMRPOVE sites located in NW, SW, NE, and SW of the U.S. (see Fig. 3 for the domain). The annual averages are listed on each panel, where $\mathrm{NHSO}=$ ammonium sulfate and $\mathrm{DU}_{f}=$ fine mode dust.
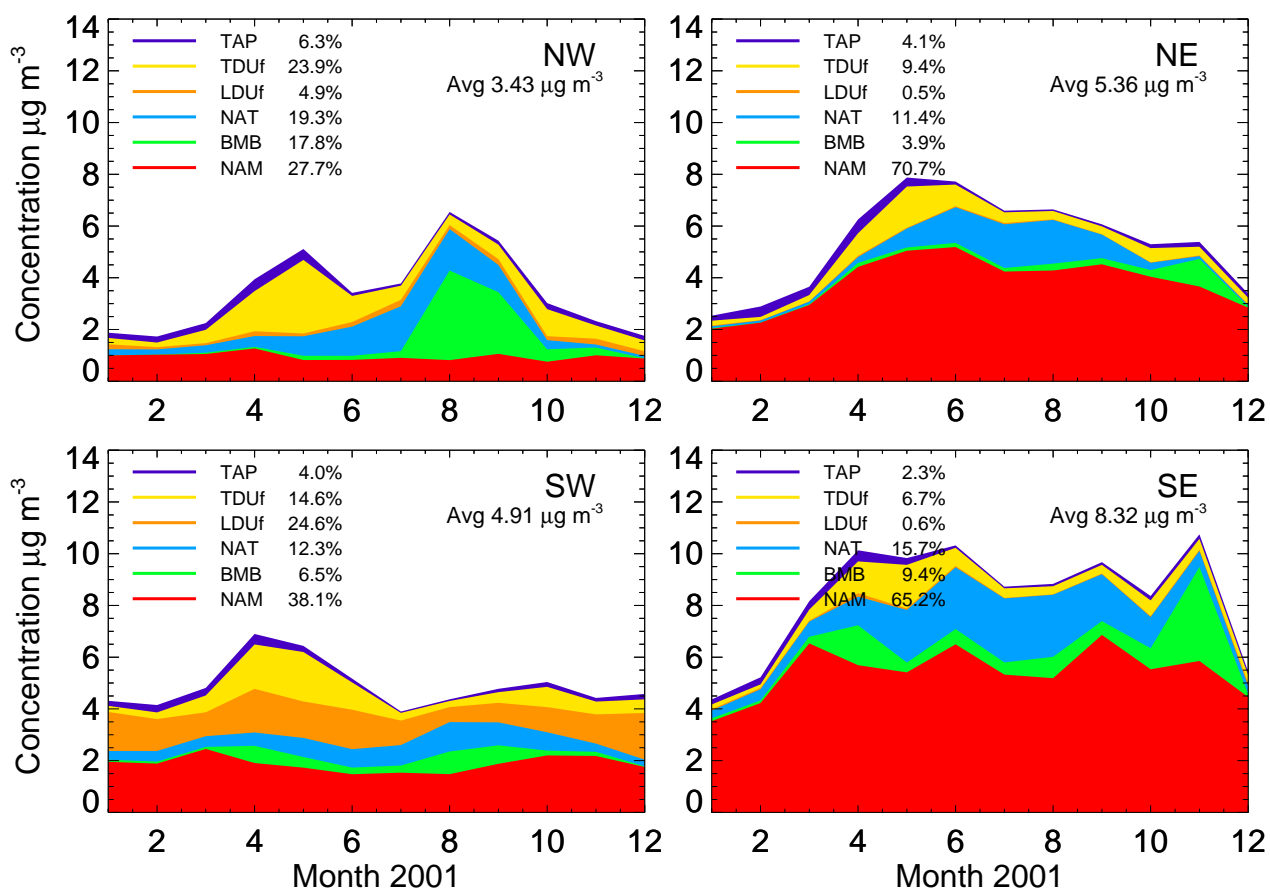

Fig. 7. Monthly and regional average of surface aerosol fine mass in NW, SW, NE, and SW (domain in Fig. 3) in the U.S. from different origins: TAP, transported air pollutants from outside North America; TDU $f$, imported fine-dust from outside North America; LDU $f$, local fine-dust; NAT, natural (biogenic and volcanic); BMB, biomass burning; NAM, North American pollution. 

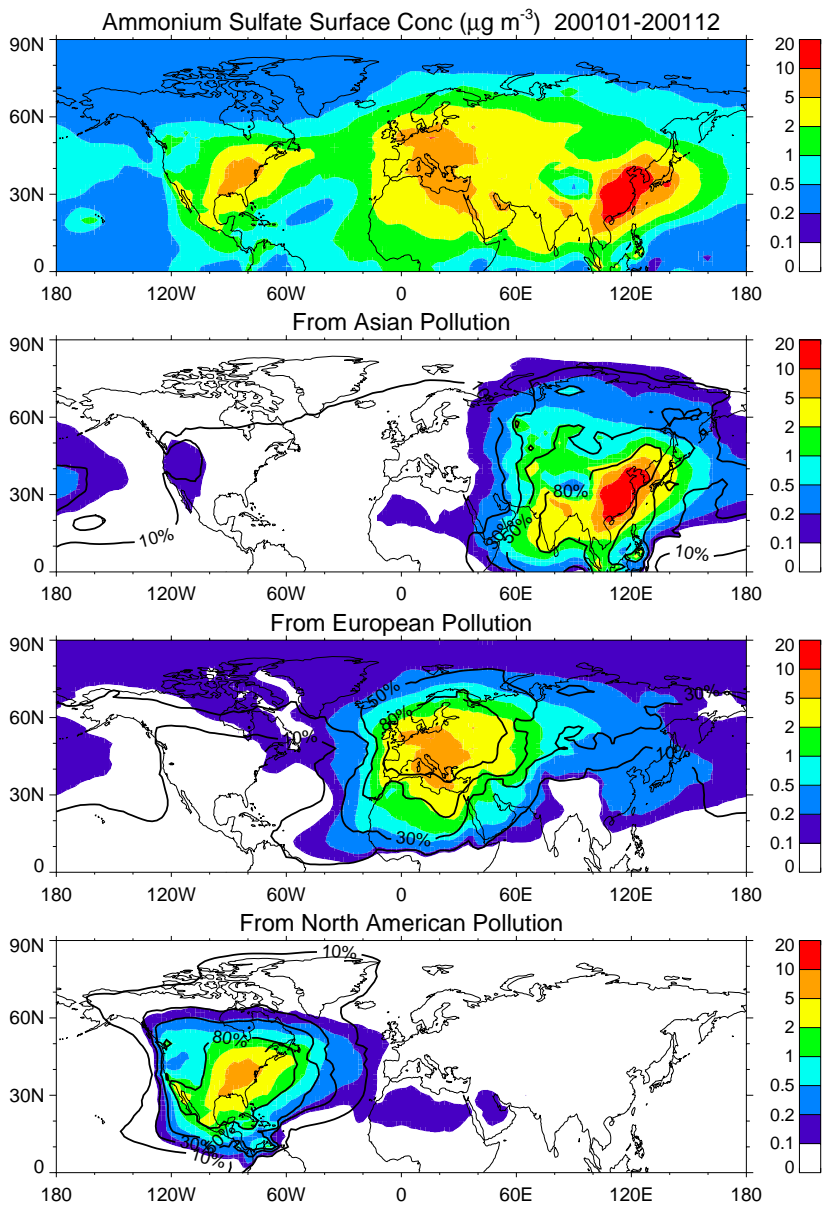

Fig. 8a. Annual average surface ammonium sulfate concentrations in the northern hemisphere in 2001 from the GOCART model (top panel) and the amount from major pollution source regions of Asia (2nd panel), Europe (3rd panel), and North America (last panel). Regional domains are shown in Fig. 1a. Color scales are concentrations in $\mu \mathrm{g} \mathrm{m}^{-3}$, and the contour lines are the percentage contributions to the total ammonium sulfate in $10,30,50,80 \%$ intervals.

from other continents have insignificant effects on the surface PM air quality over the U.S.

\section{Hemispheric influence of intercontinental transport}

Although our main focus in this paper is to assess the impact of aerosols from different types and regions on surface air quality over the U.S., we further examine the hemispheric influence of pollution and dust aerosols from their major source regions in order to gain a broader perspective on intercontinental transport influences. Because ammonium sulfate is generally the major component of pollution aerosols, we use it as a surrogate for pollution aerosols in the following analysis. The major pollution and dust source regions are shown in Fig. 1 with their emission amounts listed in Table 1. Recall that the contribution from each region is estimated from
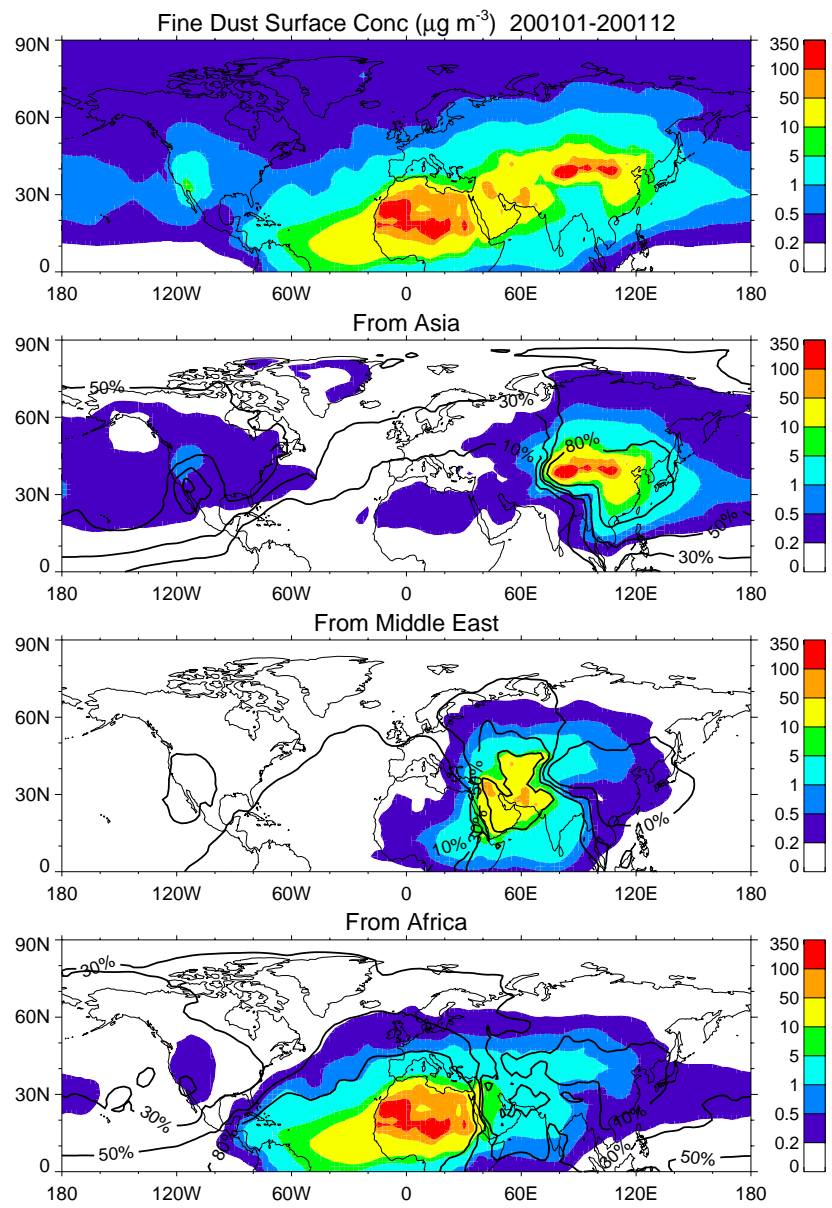

Fig. 8b. Annual average fine dust concentrations in the northern hemisphere in 2001 from the GOCART model (top panel) and the amount from major source regions of Asia (2nd panel), Middle East/Central Asia (3rd panel), and northern Africa (last panel). Regional domains are shown in Fig. 1c. Color scales are concentrations in $\mu \mathrm{g} \mathrm{m}^{-3}$, and the contour lines are the percentage contributions to the total ammonium sulfate in $10,30,50,80 \%$ intervals.

the difference between a model simulation with all emissions included and one with a particular regional emission excluded. Our previous studies have shown that the model reproduces the observed sulfate and dust concentrations and seasonal variations to within a factor of 2 in the major pollution sources regions (e.g., North America and Europe) and over the areas affected by the transport (e.g., western Pacific and North Atlantic) (Chin et al., 2000b, 2003; Ginoux et al., $2001,2004)$, providing a foundation for our assessment here.

\subsection{Pollution transport}

Figure 8a displays the annually averaged surface ammonium sulfate concentrations in the northern hemisphere in 2001 and contributions from pollution sources in Asia, Europe, and North America. Over East Asia, the surface ammonium sulfate concentration is about twice as high as that over the 
Table 3. Model-calculated annual averaged surface concentrations of RCFM and its composition and origins for the four quadrants in the U.S.

\begin{tabular}{lcccc}
\hline Conc. $\left(\mu \mathrm{g} \mathrm{m}^{-3}\right)$ & NW & SW & NE & SE \\
\hline RCFM & 3.43 & 4.91 & 5.36 & 8.32 \\
Composition: & & & & \\
$\left(\mathrm{NH}_{4}\right)_{2} \mathrm{SO}_{4}$ & $1.03(29.9 \%)$ & $1.70(34.7 \%)$ & $3.31(61.7 \%)$ & $4.98(59.9 \%)$ \\
$\mathrm{OM}_{\mathrm{BC}}$ & $1.27(37.1 \%)$ & $1.05(21.4 \%)$ & $1.21(22.5 \%)$ & $2.33(28.0 \%)$ \\
$\mathrm{DU}_{f}$ & $0.15(4.3 \%)$ & $0.24(4.8 \%)$ & $0.32(5.9 \%)$ & $0.39(4.7 \%)$ \\
Origin: & $0.99(28.8 \%)$ & $1.93(39.2 \%)$ & $0.53(9.9 \%)$ & $0.62(7.4 \%)$ \\
NAM & & & & \\
BMB $_{\text {NAT }}$ & $0.95(27.7 \%)$ & $1.87(38.1 \%)$ & $3.79(70.7 \%)$ & $5.43(65.2 \%)$ \\
LDU $_{f}$ & $0.61(17.8 \%)$ & $0.32(6.5 \%)$ & $0.21(3.9 \%)$ & $0.78(9.4 \%)$ \\
TDU $_{f}$ & $0.17(4.9 \%)$ & $1.22(24.8 \%)$ & $0.03(0.5 \%)$ & $0.05(0.6 \%)$ \\
TAP $^{0.82(23.9 \%)}$ & $0.72(14.6 \%)$ & $0.50(9.4 \%)$ & $0.56(6.7 \%)$ \\
\hline
\end{tabular}

$\left(\mathrm{NH}_{4}\right)_{2} \mathrm{SO}_{4}$ : ammonium sulfate. NAM = North America pollution; BMB = biomass burning; NAT = Natural (biogenic and volcanic); DU $f$ $=$ fine dust $(d<2.5 \mu \mathrm{m}) ; \mathrm{LDU}_{f}=$ fine dust from local source; $\mathrm{TDU}_{f}=$ fine dust from intercontinental transport; and TAP = pollution aerosol from intercontinental transport. Total "background" is the amount of aerosols not from North America pollution source (RCFM - NAM), total "transport" aerosol is the sum of TDU $f$ and TAP, total pollution aerosol is the sum of NAM and TAP, and total "native" is the aerosol from the North American sources (NAM+BMB+NAT).

eastern U.S. and Europe (top panel, Fig. 8a), due to higher emission of $\mathrm{SO}_{2}$ (Table 1) and faster oxidation rate of $\mathrm{SO}_{2}$ to form sulfate (Chin et al., 2000b). As expected, pollution sources exert the largest impact on their own regions and neighboring oceans (2nd to 4th panels in Fig. 8a) where more than $80 \%$ of the surface sulfate in the source regions and $50 \%$ over neighboring oceans are from regional pollution.

Most of the Asian pollution export moves toward the east across the Pacific Ocean, increasing the ammonium sulfate at the surface over the western U.S. by $0.1-0.2 \mu \mathrm{g} \mathrm{m}^{-3}$ on an annual average (2nd panel in Fig. 8a). Some of the pollution is transported westward to add $0.1-0.5 \mu \mathrm{g} \mathrm{m}^{-3}$ ammonium sulfate to eastern Europe and Middle East, and more than $0.1 \mu \mathrm{g} \mathrm{m}^{-3}$ to North Africa. Even so, Asian emission results in no more than a $10 \%$ increase of surface sulfate to downwind continents on an annual average except Canada and Greenland (2nd panel in Fig. 8a). A major pathway of the trans-Pacific transport from Asia to North America involves the uplifting of Asian air followed by a rapid horizontal transport in the prevailing westerlies and subsidence over the western part of North America (e.g. Liang et al., 2004). The large gradient of Asian pollution sulfate between the east coast of Asia and the west coast of North America (a factor of 50 to 100) implies a combined effect of plume height and efficient removal of sulfate during transport. Most pollution sulfate is located within the boundary layer upon leaving the Asian coast, as observed during the ACE-Asia experiment (e.g., Anderson et al., 2003; Chin et al., 2003; also see Sect. 5.3), making it susceptible to fast removal; only the fraction entrained in the westerly jet can make the long journey across the Pacific. Our results thus suggest that Asian pollution does not have a large potential to affect the surface fine particle mass concentrations on other continents despite its high emission rates.

European pollution, on the other hand, is more widely spread than the Asian pollution (3rd panel in Fig. 8a). It provides about $0.1-0.2 \mu \mathrm{g} \mathrm{m}^{-3}$ of ammonium sulfate to the entire Arctic surface, $0.2-2 \mu \mathrm{g} \mathrm{m}^{-3}$ to northern Asia, and 0.2$0.5 \mu \mathrm{g} \mathrm{m}^{-3}$ to eastern China. Our budget analysis shows that the amount of ammonium sulfate from European pollution on average can be $60 \%$ of that from Asian pollution over the U.S., with its strongest influence over the NE. The region which is particularly vulnerable to European pollution is northern Africa, simply because of the short traveling distance between these two continents. As much as $5 \mu \mathrm{g} \mathrm{m}^{-3}$ of ammonium sulfate over the northern African countries adjacent to the Mediterranean Sea is attributed to the European pollution source, which accounts for $50-80 \%$ of the surface sulfate budget there. It is also notable that European pollution contributes more to the surface ammonium sulfate increase over East Asia $\left(0.2-0.5 \mu \mathrm{g} \mathrm{m}^{-3}\right)$ than Asian emission contributes to North America (0.1-0.2 $\mu \mathrm{g} \mathrm{m}^{-3}$ ) on an annual average in 2001. The export of European pollution often occurs in the boundary layer (e.g. Wild et al., 2001) and usually contains a higher fraction of $\mathrm{SO}_{2}$ than does the outflow from either Asia or North America (Chin and Jacob, 1996; Chin et al., 2000b), mainly because of a slower $\mathrm{SO}_{2}$-to-sulfate transformation rate due to colder temperature. Such a combination allows continued production of sulfate within the boundary layer during transport and thus produces a broader influence on the surface sulfate concentrations. 
Table 4. Comparison of model-calculated annual-average ammonium sulfate concentration $\left(\mu \mathrm{g} \mathrm{m}^{-3}\right)$ over the western and eastern U.S. from this study and Park et al. (2004).

\begin{tabular}{lcccc}
\hline & \multicolumn{2}{c}{ Park et al. (2004) } & \multicolumn{2}{c}{ This study } \\
\hline Concentration $\left(\mu \mathrm{g} \mathrm{m}^{-3}\right)$ & Western US & Eastern US & NW/SW US & NE/SE US \\
\hline Total Concentration $_{\text {Background }}^{\mathrm{a}}$ & 1.52 & 4.11 & $1.03 / 1.70$ & $3.31 / 4.98$ \\
From Asia $_{\text {From Europe }}^{\mathrm{b}}$ & 0.28 & 0.24 & $0.29 / 0.30$ & $0.25 / 0.26$ \\
& 0.13 & 0.12 & $0.12 / 0.11$ & $0.07 / 0.08$ \\
& $\leq 0.04$ & $\leq 0.01$ & $0.06 / 0.05$ & $0.08 / 0.06$ \\
\hline
\end{tabular}

a The background value in this study is defined as the amount of ammonium sulfate from non-North American pollution sources, which is equivalent to the values of "background from non-U.S. anthropogenic emission" minus the transboundary transport from Canada and Mexico to the U.S. in Park et al. (2004) (western: $0.43-0.15=0.28 \mu \mathrm{g} \mathrm{m}^{-3}$, eastern: $0.38-0.14=0.24 \mu \mathrm{g} \mathrm{m}^{-3}$ ).

b Although the amount from Europe is not explicitly listed in Park et al. (2004), the difference between "Transboundary transport" and "Natural" in Table 2 of Park et al. (2004) implies the maximum amount of ammonium sulfate transported from Europe (R. Park, personal communication).

Relative to the spatial spreading of Asian and European sulfate, North America pollution is more regionalized (4th panel in Fig. 8a), but its contribution to the surface ammonium sulfate over northern Africa and Saudi Arabia (0.1$0.2 \mu \mathrm{g} \mathrm{m}^{-3}$ ) is similar to the contribution from Asia to the western U.S. It has been suggested that the North American influence over northern Africa and the Middle East is due to the deep boundary layer mixing over those arid regions that entrains the plume from aloft (Li et al., 2001).

Our results for total and "background" ammonium sulfate surface concentrations and the Asian influences over the U.S. are similar to the equivalent quantities from the GEOSCHEM model simulations for the same year (2001) that also used the GEOS-3 meteorological fields (Park et al., 2004). As summarized in Table 4, we see the major difference between the two studies is in the European influence over the eastern U.S. We have found that the pollution transport from Europe and Asia is of comparable importance, but the budget shown in Park et al. (Table 2 in Park et al., 2004) implies negligible influence from European pollution, although the European budget was not explicitly calculated in that study. Differences in emission and budget classification from our different model experiment designs may explain the apparent discrepancy, which is expected to be resolved through the modeling exercise in the current United Nation Task Force assessment of Hemispheric Transport of Atmospheric Pollutants (http://www.htap.org), in which common pollution regions of North America, Europe, East Asia, and South Asia are defined by the Task Force for all participating models including GOCART and GEOS-CHEM.

\subsection{Dust transport}

The annual surface concentrations of fine dust and contributions from major source regions in Asia, Middle East, and North Africa are shown in Fig. $8 \mathrm{~b}$ (note that the color scale is different from Fig. 8a). A clear dust band with fine dust concentrations above $5 \mu \mathrm{g} \mathrm{m}^{-3}$ expands from the sub-tropical North Atlantic to northeastern Asia (1st panel in Fig. 8b). Away from the source regions, Asian dust seems to have the largest influence on the surface fine dust over extra-tropical North Pacific and North America, with a contribution of 0.2$1 \mu \mathrm{g} \mathrm{m}^{-3}$. The concentration gradient across the Pacific for dust is a factor of about 20 (e.g., the dust concentration off the coast of China is about 20 times higher than that at the west coast of North America), which is much smaller than the concentration gradient of sulfate that we saw earlier, suggesting a more efficient trans-Pacific transport of dust than sulfate. This is because the higher elevation of the Asian dust plume (above the boundary layer upon leaving Asia, e.g., Anderson et al., 2003; Chin et al., 2003; also see Sect. 5.3) and the lower wet scavenging efficiency results in a slower loss rate of dust than sulfate during trans-Pacific transport. Over the Arctic, above 50\% (or $>0.1 \mu \mathrm{g} \mathrm{m}^{-3}$ ) of the surface fine dust is from Asia, an amount that is comparable to the European pollution contribution to Arctic sulfate (Fig. 8a). These results have yet to be verified with surface measurements, although the optical measurements in April 2002 at the Alaska baseline observatory in Barrow detected the clear existence of dust for several days that was traced back to the Gobi desert by a trajectory analysis (Stone et al., 2005).

Dust emitted from the Middle East has the highest impact over India, northeastern Africa, and North Indian Ocean with an increase of $1-5 \mu \mathrm{g} \mathrm{m}^{-3}$ (3rd panel in Fig. 8b); it can also travel to northern and eastern Asia and to eastern Africa. The northward transport delivers dust that accounts for more than $10 \%$ of the surface fine dust concentrations in the Arctic.

The vast desert area over Africa is the largest dust source on the globe. Much of dust uplifted there is transported westward across the Atlantic under the influence of trade winds to arrive at Central America and equatorial South America, whereas the northward transport over the Mediterranean is 

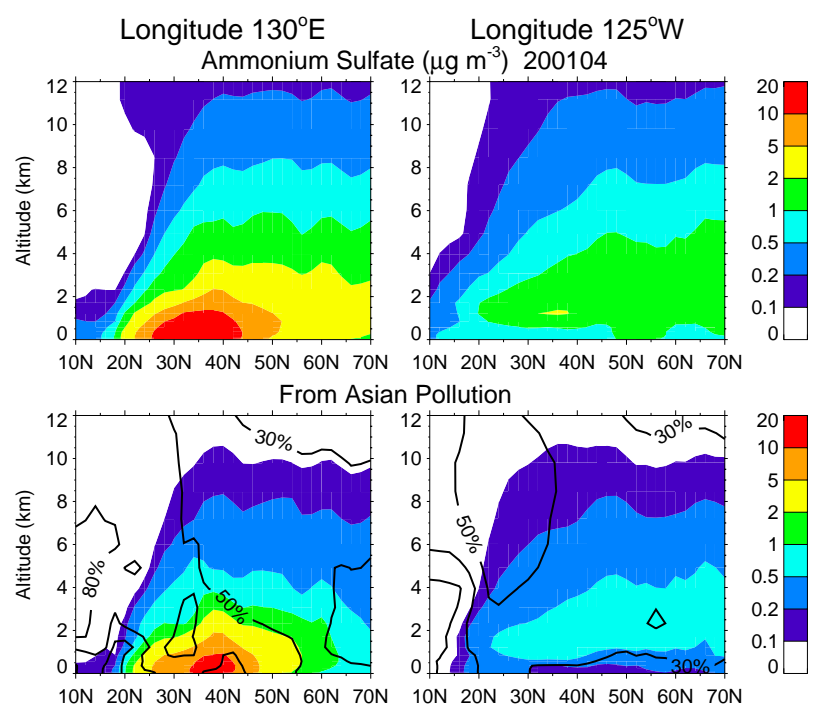
From European Pollution

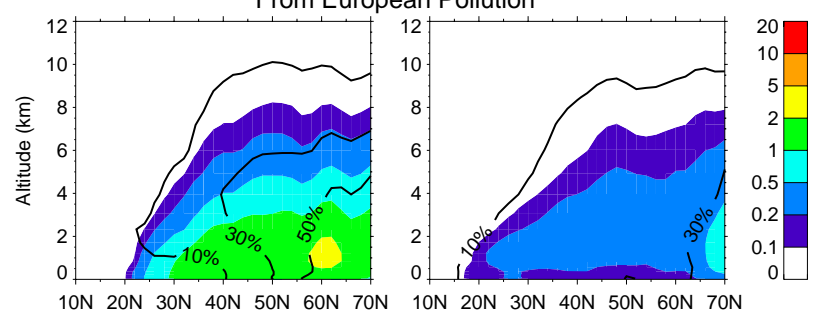

From North American Pollution

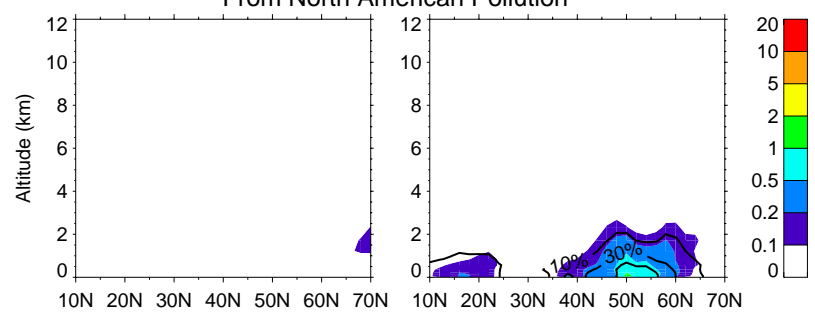

Fig. 9a. Vertical cross-sections of ammonium sulfate concentrations in April 2001 along the exit boundary of the Asian outflow $\left(130^{\circ} \mathrm{E}\right.$, left column) and the entrance boundary of the North American inflow $\left(125^{\circ} \mathrm{W}\right.$, right column). Total ammonium sulfate (top row) and amount from Asian pollution (2nd row), European pollution (3rd row), and North American pollution (4th row) are shown in color scales in $\mu \mathrm{g} \mathrm{m}^{-3}$, and the percentage contributions to the total ammonium sulfate in $10,30,50,80 \%$ intervals are plotted with countor lines. Source regions are given in Fig. 1a.

linked to the presence of cyclones (Prospero, 1996; Moulin et al., 1997) to reach southern Europe. Both pathways bring $1-5 \mu \mathrm{g} \mathrm{m}^{-3}$ of fine dust to the surface of affected areas (4th panel in Fig. 8b). There is also an eastward transport pathway that takes the African dust to Asia, traveling a long distance in the mid-tropospheric westerlies across the North Pacific to eventually subside in western North America, raising fine dust levels by $0.2-0.5 \mu \mathrm{g} \mathrm{m}^{-3}$ at the surface. While the transAtlantic and cross-Mediterranean transport of African dust is frequently detected by satellite (e.g., MODIS data in Fig. 1),
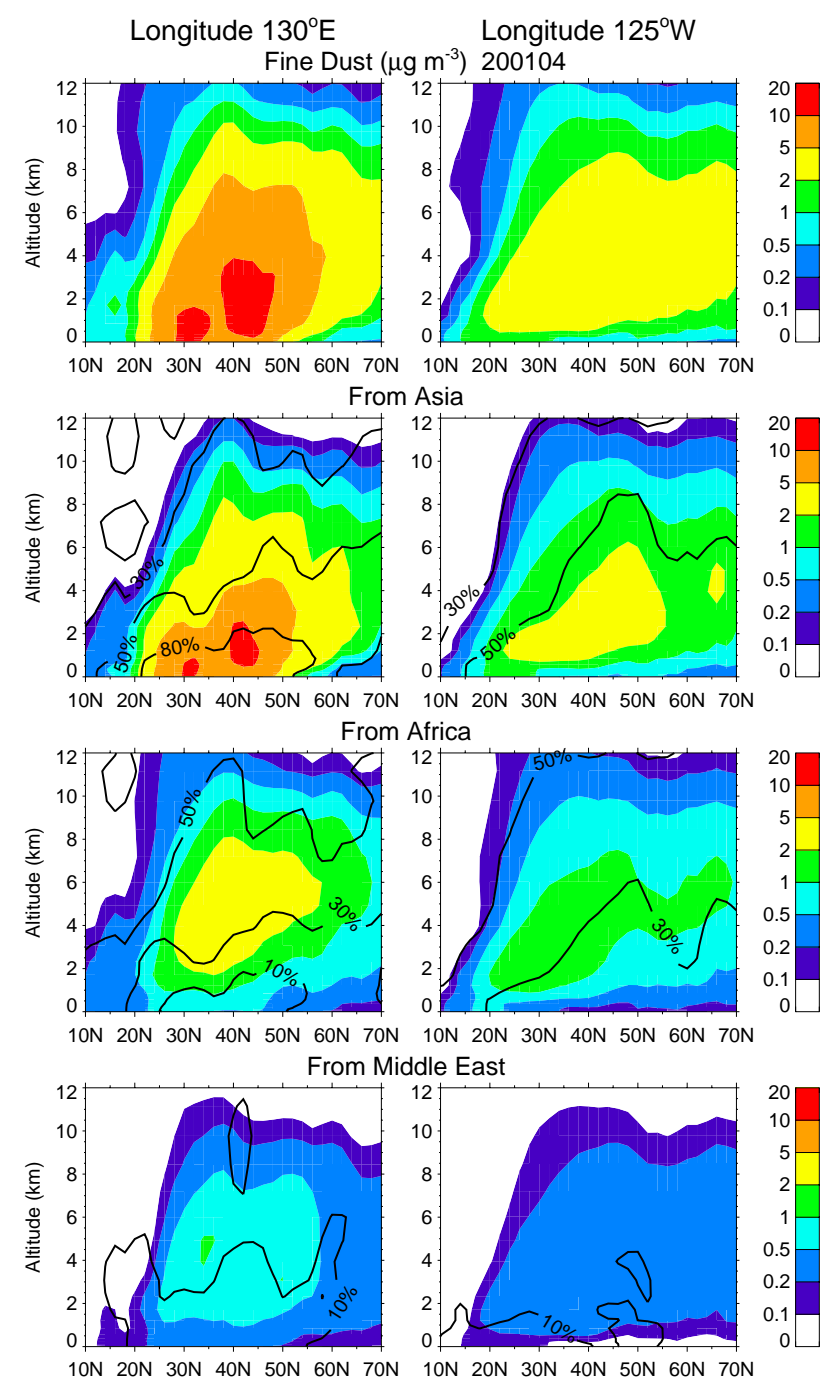

Fig. 9b. Vertical cross-sections of fine mode dust concentrations in April 2001 along the exit boundary of the Asian outflow $\left(130^{\circ} \mathrm{E}\right.$, left column) and the entrance boundary of the North American inflow ( $125^{\circ} \mathrm{W}$, right column). Total dust (top row) and amount from major source regions of Asia (2nd row), Africa (3rd row), and Middle East (4th row) are shown in color scales in $\mu \mathrm{g} \mathrm{m}^{-3}$, and the percentage contributions to the total fine mode dust in $10,30,50$, $80 \%$ intervals are plotted with countor lines. Source regions are given in Fig. 1c.

the trans-Pacific transport of African dust is difficult to recognize because it easily loses its distinct characteristics after merging with the Asian dust. A recent study has reported detection of dust over western Canada, which was attributed to long-range transport of Saharan dust through a pathway spanning from Asia and the North Pacific to western North America in the absence of any Asian dust activities (McKendry et al., 2007); this finding is supported by our modeling results. 


\subsection{Plume height}

The impact of long-range transport on air quality depends not only on the amount that is being transported out from the source region but also on the fraction of the plume that can reach the surface at the receptor region. As an example for trans-Pacific transport, Fig. 9 shows the latitude-vertical cross-sections of ammonium sulfate and fine dust in April 2001, i.e. the season of maximum trans-Pacific transport, at two longitudes: $130^{\circ} \mathrm{E}$, representing the exit boundary of Asian outflow; and $125^{\circ} \mathrm{W}$, representing the entrance boundary of North American inflow. Similar to Fig. 8, the total amount and the amount from different major source regions are shown separately in each panel.

Figure 9 corroborates what we have discussed in the previous two sections (5.1 and 5.2). At the east coast of Asia $\left(130^{\circ} \mathrm{E}\right)$, the maximum ammonium sulfate concentration (5$20 \mu \mathrm{g} \mathrm{m}^{-3}$ ) is located at the lowest $1 \mathrm{~km}$ in the mid-latitudes (Fig. 9a, top left panel), with most of it from Asian industrial pollution sources (2nd left panel). Yet, the European industrial pollution can account for a significant fraction of the boundary layer ammonium sulfate $\left(1-2 \mu \mathrm{g} \mathrm{m}^{-3}\right)$ in the "Asian outflow" at latitudes $30^{\circ} \mathrm{N}$ or higher ( 3 rd left panel). In comparison with the vertical profile near the Asian coast, ammonium sulfate at the North American inflow boundary $\left(125^{\circ} \mathrm{W}\right)$ is situated at a higher altitude with a peak value at about $1.5 \mathrm{~km}$ (Fig. 9a, top right panel), resulting from a combination of sulfate deposition near the surface and the uplift of the plume during trans-Pacific transport. Thus, the transPacific pollution brings major influence above the surface over North America (about 60\%, with 2/3 from Asian and $1 / 3$ from European pollution) but only a relatively minor impact on the surface ammonium sulfate concentrations (0.2$0.5 \mu \mathrm{g} \mathrm{m}^{-3}$ ) (2nd and 3rd right panels). The North American industrial pollution starts to show its importance off the west coast (4th right panel) even though the prevailing westerly winds in spring allow only minimum transport of pollution from inland to the adjacent Pacific Ocean.

Compared with ammonium sulfate, fine mode dust at the east coast of Asia extends to a wider range vertically with a maximum above the surface (Fig. 9b, 1st left panel). While more than $80 \%$ of this dust below $3-5 \mathrm{~km}$ comes from the Asian dust sources (2nd left panel), dust from Africa could contribute to more than $30 \%$ above $3-4 \mathrm{~km}$ and more than $50 \%$ in the upper troposphere ( $3 \mathrm{rd}$ left panel). Like sulfate, dust is lifted higher over the west coast of North America with a minimum value near the surface (Fig. 9b, top right panel). While Asian dust dominates the total dust at the North American inflow boundary $\left(125^{\circ} \mathrm{W}\right)$ in the lower troposphere over mid-latitudes (2nd right panel), African dust inputs a comparable amount in the middle to upper troposphere (3rd right panel). Dust from the Middle East accounts for less than $10 \%$ at both sides of the North Pacific Ocean (panels in the last row).
The results we have obtained from trans-Pacific transport in April 2001 are consistent, feature-wise, with that of Hadley et al. (2007), where they used a domain-expanded regional model CFORS (covering $15^{\circ} \mathrm{N}-85^{\circ} \mathrm{N}, 110^{\circ} \mathrm{E}-$ $105^{\circ} \mathrm{W}$ ) to study the trans-Pacific transport of $\mathrm{BC}$ and fine aerosol mass from Asia to North America in spring 2004. They estimated that at locations close to the North American inflow boundary $\left(130^{\circ} \mathrm{W}\right)$, about $30 \%$ of $\mathrm{BC}$ near the surface and more than $75 \%$ above $3 \mathrm{~km}$ was from Asia, a pattern rather similar to our sulfate results in Fig. 9a. While Hadley et al. (2007) point to the importance of the long-range transport of Asian pollution on the climate forcing over North America, our study here addresses the impact of this transport on surface air quality, which is relatively small compared to the North America's own sources, because the transported aerosol mass mainly stays above the surface unless there is a strong subsidence or boundary layer-lower troposphere layer exchange to bring the imported aerosol mass down to the surface.

\section{Summary and conclusions}

In summary, we have used the GOCART model to estimate the origins of the surface fine aerosol particle concentrations over the U.S. that are generated from North American industrial pollution, biomass burning, and natural sources, as well as from intercontinental transport from other major source regions. Comparisons of model-simulated surface concentrations of sulfate, $\mathrm{OC}, \mathrm{BC}$, fine dust, and total RCFM with observations in 2001 at 135 sites in the IMPROVE network have revealed that the model captures the spatial and temporal variations of the observed sulfate with high correlation and low bias, but predicts higher fine dust and lower nonbiomass burning carbonaceous aerosols than the IMPROVE derived data. This discrepancy may be explained in part by model deficiencies and in part by the relatively high uncertainties in the data. The quantity of RCFM from the IMPROVE sites agrees with the model in both concentration and spatial variation. The model estimates that ammonium sulfate in the eastern U.S. is the dominant component $(\sim 60 \%)$ of the surface RCFM in all seasons, whereas in the western U.S., dust and OM are just as important as sulfate but have considerable seasonal variations, especially in the NW. The annual averaged RCFM concentrations in the NW, SW, NE, and SW quadrants in the U.S. are calculated at 3.43, 4.91, 5.36, $8.32 \mu \mathrm{g} \mathrm{m}^{-3}$, respectively, for 2001 .

By targeting individual source types and source regions in our model experiments, we have been able to place the surface RCFM in the context of regional industrial pollution, biomass burning, natural emissions, and intercontinental transport. We have found that North America regional pollution accounts for $65-70 \%$ of the surface RCFM in the eastern U.S. and nearly $30-40 \%$ in the western U.S. Of the "background" RCFM, namely the RCFM from sources other 
than North American pollution, fine dust is the most important component in the western U.S., comprising 30-40\% of the total surface RCFM in that region; while almost half of the fine dust in the NW is from Asia, more than $60 \%$ in the $\mathrm{SW}$ is from local desert areas. In the eastern U.S., however, natural aerosols, mostly OM from terpene oxidation, are the most significant contributor to background RCFM, especially in the summer. Biomass burning aerosols account for about $4-18 \%$ of total surface RCFM on an annual average, yet they have shown very strong seasonal variations and could well become the predominant RCFM component during the burning season.

The total amount of imported RCFM from outside North America varies from $9 \%$ in the SE to $30 \%$ in the NW, consisting of dust and pollution with the proportion of dust being 2 to 4 times higher than that of pollution. We should note that large episodic events, such as dust storms in Asia, can create intermittent air quality problems over North America, especially over the west coast, even though these events are usually short-lived. On an annual average, pollution transport from outside of North America contributes only 2 to $6 \%$ to the total RCFM over the U.S., with NW being the most affected area. Even though the nitrate aerosols are not included in the RCFM, our source attributions for RCFM are applicable for $\mathrm{PM}_{2.5}$ (which is a commonly used indicator for air quality) in general, because the nitrate concentrations are low in most places except in California (Malm et al., 1994, 2003), and the long-range transport of nitrate seems to have negligible effects on the surface PM concentrations over the U.S. (Park et al., 2004). Our results thus suggest that controlling North American pollution emission is both the most responsible and the most effective way to manage the surface PM air quality within the region.

We have also examined the extent to which pollution and dust emissions from their major source regions may affect PM surface concentrations on a hemispheric scale. Using sulfate as a proxy for pollution aerosols, we have found that of the three major industrial pollution regions of Asia, Europe, and North America, Asian pollution contributes to more than $30 \%$ of the surface sulfate over an extended area in the North Pacific and North Indian Oceans and to between 10 and $30 \%$ over the Arctic, but to no more than $10 \%$ everywhere else, including North America. North America pollution exerts a strong impact on the western North Atlantic but generates only a limited influence on other continents, even though North Africa and the Middle East seem to receive more North American pollution than other places do. In comparison, European pollution has the largest potential to affect fine particulate levels over other continents due to the shorter traveling distance to receptor continents and the larger fraction of sulfate-producing precursor gas in the predominantly boundary layer outflow. While European pollution exhibits its largest influence over northern Africa, it can increase the surface ammonium sulfate concentration over eastern Asia by $0.2-0.5 \mu \mathrm{g} \mathrm{m}^{-3}$, an amount which is twice as high as the level of the Asian pollution impact we have found on western North America. Interestingly, the amount of the pollution ammonium sulfate Europe sends to northern Africa $\left(1-5 \mu \mathrm{g} \mathrm{m}^{-3}\right)$ is about the same as the amount of fine dust Africa sends to southern Europe on an annual average.

Of the three major dust source regions, the model has indicated that eastern Asia displays the greatest influence over the North Pacific, North America, and the Arctic, whereas Africa dominates the entire North Atlantic, tropical Pacific, Central America, and tropical South America. Nearly 3 times lower in emission rate (Table 1), Asian dust therefore has a larger "impact potential" than African dust to affect a wide geographic area. We have also found that the transPacific transport of Asian dust is much more effective than that of Asian sulfate because of the higher plume elevation and lower loss of dust during transport. We have noticed that even though the transport of African dust mostly takes place across the North Atlantic and Mediterranean regions, it can go eastward through a pathway spanning across Asia and North Pacific to settle down over the surface of western North America. The smallest influential dust region is the Middle East, whose impacts are mostly sustained by its neighbors of the northern Indian Ocean, Eastern Europe, and India, even though it can increase the fine dust over the Arctic surface by about $20 \%$.

The example of trans-Pacific transport of pollution and dust in our study has suggested that the Asian outflow should have a larger impact on regional climate than on surface air quality over North America, because the transported plume is usually located at altitudes above the surface. Our study has also shown that column-wise, the so-called "Asian outflow" in spring 2001 contains $20-30 \%$ of aerosols that do not originate in Asia, namely pollution from Europe and dust from Africa, which had been transported to Asia and then merged with Asian pollution and dust. These contributions have been largely unrecognized or overlooked in previous studies owing mainly to the difficulties in separating origins of aerosols in the Asian outflow from observations.

We should point out that the pollutant emission we used in this work is based on the "present day emission scenario" used in the IPCC 2001 Third Assessment Report (Penner et al., 2001). As economic growth and environmental regulations in the major industrial regions may have changed since then and will change in the future, pollutant emissions and consequently the extent of their impacts for different time periods are expected to be different from the ones discussed in this study. Dust and biomass burning emissions have considerable year-to-year variations; as such, the year of 2001 may not be a "typical" year to generalize the impact. In addition, our model results need to be further evaluated with observations, especially in Asia and Arctic, where data in those areas are sparse or inaccessible. Lastly, results from other models may deviate from ours, as several intercomparison studies have shown considerable differences in aerosol composition and vertical distribution (Barrie et al., 2001; Penner et al., 
2002; Textor et al., 2006). Nonetheless, our study should provide guidance not only for current regional air quality management but also for projecting future intercontinental impacts.

Acknowledgement. We appreciate the comments from an anonymous reviewer and the ACP Editor. This work is supported by NASA Atmospheric Composition Modeling and Analysis Program and Radiation Sciences Program. The IMPROVE Program is gratefully acknowledged.

Edited by: J. G. Murphy

\section{References}

Anderson, T. L., Masonis, S. J., Covert, D. S., and Ahlquist, N. C.: Variability of aerosol optical properties derived from in situ aircraft measurements during ACE-Asia, J. Geophys. Res., 108(D23), 8647, doi:0.1029/2002JD003247, 2003.

Barrie, L. A., Yi, Y., Leaitch, W. R., Lohmann, U., Kasibhatla, P., Roelofs, G. J., Wilson, J., McGovern, F., Benkovitz, C., Melieres, M. A., Law, K., Prospero, J., Kritz, M., Bergmann, D., Bridgeman, C., Chin, M., Christensen, J., Easter, R., Feichter, J., Land, C., Jeuken, A., Kjellstrom, E., Koch, D., and Rasch, P.,: A comparison of large-scale atmospheric sulphate aerosol models (COSAM): overview and highlights, Tellus B, 53(5), 615-645, 2001.

Bertschi, I. T., Jaffe, D. A., Jaegle, L., Price, H. U., and Dennison, J. B.: PHOBEA/OTCT 2002 airborne observations of transpacific transport of ozone, $\mathrm{CO}$, volatile organic compounds, and aerosols to the northeast Pacific: Impacts of Asian anthropogenic and Siberian boreal fire emissions, J. Geophys. Res., 109, D23S12, doi:10.1029/2003JD004328, 2004.

Chin, M. and Jacob, D. J.: Anthropogenic and natural contributions to tropospheric sulfate: A global model analysis, J. Geophys. Res., 101, 18 691-18 699, 1996.

Chin, M., Rood, R. B., Lin, S.-J., Müller, J.-F., and Thompson, A. M.: Atmospheric sulfur cycle simulated in the global model GOCART: Model description and global properties, J. Geophys. Res., 105, 24 671-24 687, 2000a.

Chin, M., Savoie, D. L., Huebert, B. J., Bandy, A. R., Thornton, D. C., Bates, T. S., Quinn, P. K., Saltzman, E. S., and De Bruyn, W. J.: Atmospheric sulfur cycle in the global model GOCART: Comparison with field observations and regional budgets, J. Geophys. Res., 105, 24 689-24 712, 2000 b.

Chin, M., Ginoux, P., Kinne, S., Torres, O., Holben, B. N., Duncan, B. N., Martin, R. V., Logan, J. A., Higurashi, A., and Nakajima, T.: Tropospheric aerosol optical thickness from the GOCART model and comparisons with satellite and sunphotometer measurements, J. Atmos. Sci., 59, 461-483, 2002.

Chin, M., Ginoux, P., Lucchesi, R., Huebert, B., Weber, R., Anderson, T., Masonis, S., Blomquist, B., Bandy, A., and Thornton, D.: A global model forecast for the ACE-Asia field experiment, J. Geophys. Res., 108(D23), 8654, doi:10.1029/2003JD003642, 2003.

Chin, M., Chu, D. A., Levy, R., Remer, L., Kaufman, Y., Holben, B. N., Eck, T., and Ginoux, P.: Aerosol composition and distributions in the northern hemisphere during ACE-Asia: Results from global model, satellite observations, and surface sunphotometer measurements, J. Geophys. Res., 109, D23S90, doi:10.1029/2004JD004829, 2004.

Cooke, W. F., Liousse, C, Cachier, H., and Feichter, J.: Construction of a $1^{\circ} \times 1^{\circ}$ fossil fuel emission data set for carbonaceous aerosol and implementation and radiative impact in the ECHAM4 model, J. Geophys., Res., 104, 22 137-22 162, 1999.

Duncan, B. N. and Bey, I.: A modeling study of the export pathways of pollution from Europe: Seasonal and interannual variations (1987-1997), J. Geophys. Res., 109, D08301, doi:10.1029/2003JD004079, 2004.

Ginoux, P., Chin, M., Tegen, I., Prospero, J., Holben, B., Dubovik, O., and Lin, S.-J.: Sources and distributions of dust aerosols simulated with the GOCART model, J. Geophys. Res., 106, $20225-$ $20273,2001$.

Ginoux, P., Prospero, J., Torres, O., and Chin, M.: Long-term simulation of dust distribution with the GOCART model: Correlation with the North Atlantic Oscillation, Environ. Modell. Softw., 19, 113-128, 2004.

Guerova, G., Bey, I., Attlé, J.-L., Martin, R. V., Cui, J., and Sprenger, M.: Impact of transatlantic transport episodes on summertime ozone in Europe, Atmos. Chem. Phys., 6, 2057-2072, 2006 ,

http://www.atmos-chem-phys.net/6/2057/2006/.

Hadley, O. L., Ramanathan, V., Carmichael, G. R., Tang, Y., Corrigan, C. E., Roberts, G. C., and Mauger, G. S., Trans-Pacific transport of black carbon and fine aerosol $(\mathrm{D}<2.5 \mu \mathrm{m})$ into North America, J. Geophys. Res., 112, D05309, doi:10.1029/2006JD007632, 2007.

Heald, C. L., Jacob, D. J., Park, R. J., Alexander, B., Fairlie, T. D., Yantosca, R. M., and Chu, D. A.: Transpacific transport of Asian anthropogenic aerosols and its impact on surface air quality in the United States, J. Geophys. Res., 111, D14310, doi:10.1029/2005JD006847, 2006.

Husar, R. B., Tratt, D. M., Schichtel, B. A., Falke, S. R., Li, F., Jaffe, D., Gasso, S., Gill, T., Lanlainen, N. S., Lu, F., Reheis, M. C., Chun, Y., Westphal, D., Holben, B. N., Gueymard, C., McKendry, I., Kuring, N., Feldman, G. C., McClain, C., Frouin, R. J., Merrill, J., DuBois, D., Vignola, F., Murayama, T., Nickovic, S., Wilson, W. E., Sassen K., Sugimoto, N., and Malm, W. C.: Asian dust events of April 1998, J. Geophys. Res., 106, 18 317-18330, 2001.

Intergovernmental Panel on Climate Change (IPCC), Climate Change 2001: The Scientific Basis, edited by: Houghton, J. T., Ding, Y., Nogua, M., et al., Cambridge University Press, New York, 2001.

Jaffe, D., McKendry, I., Anderson, T., and Price, H.: Six "new" episodes of trans-Pacific transport of air pollutants, Atmos. Environ., 37(3), 391-401, 2003.

Koch, D. and Hansen, J.: Distant origins of Arctic black carbon: A Goddard Institute for Space Studies ModeE experiment, J. Geophys. Res., 110, D04204, doi:10.1029/2004JD005296, 2005.

Koch, D., Bond, T. C., Streets, D., Unger, N., and van der Werf, G. R.: Global impacts of aerosols from particular source regions and sectors, J. Geophys. Res., 112, D02205, doi:10.1029/2005JD007024, 2007.

Li, Q., Jacob, D. J., Bey, I., Yantosca, R. M., Field, B. D., Liu, H., Logan, J. A., Fiore, A. M., Martin, R. V., and Duncan, B. N.: Sources of ozone over the North Atlantic and transatlantic transport of pollution: A global model perspective, IGACtivities 
Newsl., 24, 12-17, 2001.

Li, Q., Jacob, D. J., Bey, I., Palmer, P. I., Duncan, B. N., Field, B. D., Martin, R. V., Fiore, A. M., Yantosca, R. M., Parish, D. D., Simmonds, P.G., and Oltmans, R. M.: Transatlantic transport of pollution and its effects on surface ozone in Europe and North America, J. Geophys. Res., 107(D13), 4166, doi:10.1029/2001JD001422, 2002.

Li, Q., Jacob, D. J., Park, R., Wang, Y. X., Heald, C. L., Hudman, R., Yantosca, R. M., Martin, R. V., and Evans, M. J.: North American pollution outflow and the trappin of convectively lifted pollution by upper-level anticyclone, J. Geophys. Res., 110, D10301, doi:10.1029/ 2004JD005039, 2005.

Liang, Q., Jaeglé, L., Jaffe, D. A., Weiss-Penzias, P., Heckman, A., and Snow, J.: Long-range transport of Asian pollution to the northeast pacific: Seasonal variations and transport pathways of carbon monoxide, J. Geophys. Res., 109, D23S07, doi:10.1029/2003JD004402, 2004.

Malm, W. C., Sisler, J. F., Huffman, D., Eldred, R. A., and Cahill, T. A.: Spatial and seasonal trends in particle concentration and optical extinction in the United States, J. Geophys. Res., 99, 13471370, 1994

Malm, W. C., Pitchford, M. L., Scruggs, M., Sisler, J. E., Ames, R., Copeland, S., Gebhart, K. A., and Day, D. E.: Spatial and seasonal patterns and temporal variability of haze and its constituents in the United States, Rep. III, Coop. Inst. for Res., Colorado State University, Fort Collins, CO, 2000.

Malm, W. C., Day, D. E., Kreidenweis, S. M., Collett, J. L., and Lee, T.: Humidity-dependent optical properties of fine particles during the Big Bend Regional Aerosol Visibility Observational Study, J. Geophys. Res., 108(D9), 4279, doi:10.1029/2002JD002998, 2003.

McKendry, I. G., Stawbridge, K. B., O’Neill, N. T., Macdonald, A. M., Liu, P. S. K., Leaitch, R., Anlauf, K. G., Jaegle, L., Fairlie, T. D., and Wesphal, D. L.: Trans-Pacific transport of Saharan dust to western North America: A case study, J. Geophys. Res., 112, D01103, doi:10.1029/2006JD007129, 2007.

Moulin, C., Lambert, C. E., Dulac, F., and Dayan, U., Control of atmospheric export of dust from North Africa by the North Atlantic Oscillation, Nature 387, 691-694, 1997.

Nakienovi, N., Alcamo, J., Davis, G., et al.: Emission Scenarios: A Special Report of Working Group III of the Intergovernmental Panel on Climate Change, Cambridge Univ. Press, New York, 599 pp., 2000.

Ostro, B., Chestnut, L., Vichit-Vadakan, N., and Laixuthai, A.: The impact of particulate matter on daily mortality in Bangkok, Thailand. J. Air and Waste Mangement Assoc., 49, 100-107, 1999.

Ostro, B. D., Broadwin, R., and Lipsett, M. J.: Coarse and fine particles and daily mortality in the Coachella Valley, California: a follow-up study, J. Expo. Anal. Env. Epid., 10, 412-419, 2000.

Park, R. J., Jacob, D. J., Chin, M., and Martin, R. V.: Source of carbonaceous aerosols over the United States and implications for natural visibility, J. Geophys. Res., 108(D12), 4355, doi:10.1029/2002JD003190, 2003.

Park, R. J., Jacob, D. J., Field, B. D., Yantosca, R. M., and Chin, M.: Natural and transboundary pollution influences on sulfate-nitrate-ammonium aerosols in the United States: Implications for policy, J. Geophys. Res., 109, D15204, doi:10.1029/2003JD004473, 2004.
Penner, J. E., Andreae, M., Annegarn, H., Barrie, L., Feichter J., Hegg, D., Jayaraman, A., Leaitch, R., Murphy, D., Nganga, J., Pitari, G., et al.: Aerosols, their direct and indirect effects, in: Intergovernmental Panel on Climate Change (IPCC), Climate Change 2001. The Scientific Basis, Chapter 5, edited by: Houghton, J. T., Ding, Y., Nogua, M., et al., Cambridge University Press, New York, 2001.

Penner, J. E., Zhang, S. Y., Chin, M., Chuang, C. C., Feichter, J. Feng, Y., Geogdzhayev, I. V., Ginoux, P., Herzog, M., Higurashi, A., Koch, D., Land, C., Lohmann, U., Mishchenko, M., Nakajima, T., Pitari, G., Soden, B., Tegen I., and Stowe, L.: A comparison of model- and satellite-derived aerosol optical depth and reflectivity, J. Atmos. Sci., 59(3), 441-460, 2002.

Pope, C. A., III, Burnett, R. T., Thun, M. J., Calle, E. E., Krewski, D., Ito, K., and Thurston, G. D.: Lung cancer, cardiopulmonary mortality and long-term exposure to fine particulate air pollution, J. Am. Med. Assoc., 287, 1132-1141, 2002.

Prospero, J. M.: The atmospheric transport of particles to the ocean, in Particle Flux in the Ocean, edited by: Ittekkot, V., Schäfer, P., Honjo, S., and Depetris, Wiley, New York, 19-52, 1996.

Shaw, G. E.: The Arctic haze phenomenon, B. Am. Meteorol. Soc. 76, 2403-2413, 1995.

Stohl, A. and Trickl, T.: A 1-year Lagrangian "climatology" of airstreams in the Northern Hemisphere troposphere and lowermost stratosphere, J. Geophys. Res., 106, 30 445-30 462, 1999.

Stohl, A., Eckhardt, S., Forster, C., James, P., and Spichtinger, N.: On the pathways and timescales on intercontinental air pollution transport, J. Geosphys. Res., 107(D23), 4684, doi:10.1029/2001JD001396, 2002.

Stone, R., Anderson, G., Andrews, E., Dutton, E., Harris, J., Shettle, E., Berk, A., et al.: Asian dust signatures at Barrow: observed and simulated. Incursions and impact of Asian dust over Northern Alaska, Workshop on Remote Sensing of Atmospheric Aerosols, IEEE Conference Proceedings, doi:10.1109/AERSOL.2005.1494152, 74-79, 2005.

Taylor, K. E.: Summarizing multiple aspects of model performance in a single diagram, J. Geophys. Res., 106, 7183-7192, 2001.

Textor, C., Schulz, M., Guibert, S., Kinne, S., et al.: Analysis and quantification of the diversities of aerosol life cycles within AeroCom, Atmos. Chem. Phys., 6, 1777-1813, 2006, http://www.atmos-chem-phys.net/6/1777/2006/.

van der Werf, G. R., Randerson, J. G., Collatz, G. J., and Giglio, L.: Carbon emissions from fires in tropical and subtropical ecosystems, Global Change Biol., 9, 547-562, 2003.

Wild, O. and Akimoto, H.: Intercontinental transport of ozone and its precursors in a three-dimensional global CTM, J. Geophys. Res., 106, 27 729-27 744, 2001.

World Health Organization, NIS Environment Strategy Background paper "Pollution Previention and Control", WHO Regional Office for Europe, 2002.

Yevich, R. and Logan, J. A.: An assessment of biofuel use and burning of agriculture waste in the developing world, Global Giogeochem. Cy., 17(4), 1905, doi:10.1029/2002GB001952, 2003. 